\title{
The fossil record of whip spiders: the past of Amblypygi
}

\author{
Carolin Haug ${ }^{1,2} \cdot$ Joachim T. Haug ${ }^{1,2}(\mathbb{C}$
}

Received: 29 August 2020 / Accepted: 8 February 2021 / Published online: 31 March 2021

(c) The Author(s) 2021

\begin{abstract}
Whip spiders (Amblypygi), as their name suggests, resemble spiders (Araneae) in some aspects, but differ from them by their heart-shaped (prosomal) dorsal shield, their prominent grasping pedipalps, and their subsequent elongate pair of feeler appendages. The oldest possible occurrences of whip spiders, represented by cuticle fragments, date back to the Devonian (c. 385 mya), but (almost) complete fossils are known from the Carboniferous (c. 300 mya) onwards. The fossils include specimens preserved on slabs or in nodules (Carboniferous, Cretaceous) as well as specimens preserved in amber (Cretaceous, Eocene, Miocene). We review here all fossil whip spider specimens, figure most of them as interpretative drawings or with high-quality photographs including 3D imaging (stereo images) to make the three-dimensional relief of the specimens visible. Furthermore, we amend the list by two new specimens (resulting in 37 in total). The fossil specimens as well as modern whip spiders were measured to analyse possible changes in morphology over time. In general, the shield appears to have become relatively broader and the pedipalps and walking appendages have become more elongate over geological time. The morphological details are discussed in an evolutionary framework and in comparison with results from earlier studies.
\end{abstract}

Keywords Amblypygi $\cdot$ Arachnida $\cdot$ Amber $\cdot$ Coal measures $\cdot$ Crato Formation $\cdot$ Quantitative morphology

\section{Introduction}

Amblypygi is a rather species-poor group (Harvey 2003); its representatives are known as tail-less whip scorpions or whip spiders. They are quite distinct representatives of the group Arachnida. Their body is rather flat, the shield formed by the anterior body region (prosomal shield) appears heartshaped in dorsal view. The trunk (opisthosoma) is set off distinctly from the anterior body (prosoma) by a constriction and bears distinct ventral and dorsal sclerotisations (sternites and tegites). The second pair of appendages, the pedipalps, forms ferocious grasping structures. The third pair of appendages is strongly elongated, representing functional feelers. Whip spiders are mostly predators, also cannibalising freshly moulted individuals of the same species

Handling Editor: Mike Reich.

Carolin Haug

carolin.haug@palaeo-evo-devo.info

1 Department of Biology II, Ludwig-Maximilians-Universität München, Großhaderner Str. 2, 82152 Planegg-Martinsried, Germany

2 GeoBio-Center, Ludwig-Maximilians-Universität München, Richard-Wagner-Str. 10, 80333 Munich, Germany
(Torres-Contreras et al. 2015; Chapin and Reed-Guy 2017; Torres et al. 2019). Yet, there are also reported cases of scavenging (García Rivera et al. 2009; Prous et al. 2017; Torres et al. 2019).

The group Amblypygi is estimated to include between about 150 species (Chapin and Hebets 2016: 2) and more than 200 species in the extant fauna (Miranda et al. 2016: 16). Their occurrence is largely restricted to the tropics and subtropics. Fossil representatives are still very rare. The oldest possible occurrence is a piece of cuticle of an appendage from the Devonian (about 385 million years old; Selden et al. 1991). More complete fossils clearly showing the specialisations of Amblypygi are known from the Carboniferous (about 300 million years old) of North America and Great Britain (Petrunkevitch 1913, 1949, 1953; Dunlop 1994; Dunlop et al. 2007a; Garwood et al. 2017). Fifteen specimens have so far reliably been reported, yet several specimens are only represented by isolated trunks. The next younger occurrences are known from two Cretaceous deposits: the Crato Formation of Brazil (about 110 million years old) with so far two specimens (Dunlop and Martill 2001; Dunlop and Barov 2005) and amber from Myanmar (about 100 million years old) with so far eight known specimens 
(Engel and Grimaldi 2014; Gröhn 2015; Wunderlich 2015; Xia et al. 2015; Hu et al. 2020).

Also younger ambers have yielded fossil representatives of Amblypygi. Indian Eocene Cambay amber (about 50 million years old) has provided a single, spectacular amber piece with an adult female whip spider preserved together with several small nymphs (Engel and Grimaldi 2014), indicating that already at that time, whip spiders provided brood care, just as their modern counterparts (e.g. Weygoldt 2000; Engel and Grimaldi 2014 and references therein). Miocene Middle American ambers (about 25 million years old, but possibly younger) have provided several well-preserved specimens. Two specimens come from Mexican amber (Petrunkevitch 1971; Poinar and Brown 2004; Dunlop and Mrugalla 2015). Seven specimens have been reported from Dominican amber (Schawaller 1979, 1982), even representing part of the post-embryonic ontogeny.

Rather recently, Garwood et al. (2017) reconstructed the relationships of the major lineages within Amblypygi with a focus on properly resolving the position of the Carboniferous species Weygoldtina anglica. Additionally, they reconstructed part of the character evolution and the early diversification of the group.

We here review the fossil record of Amblypygi and report additional new fossil specimens. We furthermore discuss the implications for the evolution of the group provided by these, still few, fossils.

\section{Materials and methods}

\section{Materials}

All fossil specimens depicted in the literature were included in this study. Of these illustrations, simplified line drawings were produced (see below).

Five specimens of the Carboniferous whip spider Weygoldtina anglica (originally labelled Graephonus anglicus) were documented at the Natural History Museum (NHM) London. All specimens originate from the British Coal Measures of Coseley, near Dudley, Staffordshire.

Two additional new specimens were directly inspected and documented. The first specimen is from the Sennlaub collection, Hanau. The specimen originates from the Cretaceous Crato Formation. Although not in a public collection, we provide here all raw data used for the analysis (mostly measurements) and by this provide a basis to allow reproducibility and testability of data quality. Furthermore, the specimen is not used for a taxonomic act.

The second new specimen is part of the Palaeo-Evo-Devo (PED) Research Group Collection of Arthropods, LudwigMaximilians-Universität München, Germany, PED 0099. It is preserved in Cretaceous amber from Myanmar, generally known as Burmese amber. The specimen was legally purchased on ebay.com from the trader burmite-miner.

\section{Imaging methods}

A Canon EOS Rebel T3i camera equipped with an MP-E $65 \mathrm{~mm}$ super macro lens was used to document specimens at the NHM London. Illumination was provided by a Canon MT-24EX twin flash. Light was cross-polarised; perpendicularly oriented polarisation filters were placed on lens and flashes. When necessary due to high relief, several images of the same image detail were recorded in shifting focus (stack of images). Images of each stack (frames) were fused to one sharp image using CombineZP (e.g. Haug et al. 2008). Additionally, stereo images were recorded by moving the camera around the specimen and taking images at slightly different angles. In some cases, stereo images were depth inverted, i.e. to make negative relief appear like positive relief (e.g. Haug et al. 2012, 2015).

Both newly available specimens were documented on a Keyence VHX 6000 digital microscope. In principle, we followed the approaches of composite imaging (recording of image stacks of adjacent image details, followed by fusion and stitching; e.g. Haug et al. 2008; Kerp and Bomfleur 2011) including different exposure times (HDR; Haug et al. 2013), and used the built-in software for direct processing.

Virtual surface reconstruction based on depth from defocus was performed with the built-in software. Based on these, stereo images were recorded for providing depth impression of the relief.

\section{Drawings}

Simplified drawings representing the fossils were assembled in Adobe Illustrator CS2. Drawings were mirrored based on the better preserved side. Locomotory appendages were copied based on the most completely preserved one. Also, all body parts were oriented in a rather stereotypical way. This represents a certain type of interpretation. This type of interpretation is necessary as a basis for measuring and allowing the reader to understand what was measured.

\section{Measurements}

Measurements were performed in ImageJ using the line tool and the segmented line tool. In addition to fossil specimens, also 34 extant specimens representing 26 different species, covering the phylogenetic range of Amblypygi, were measured based on images from the literature. For many specimens, especially for extant ones, no scales are available. Therefore, only ratios could be used for a wider comparative frame (Table 1). Measured distances (Fig. 1) include the length and width of the prosomal shield (in the following 
Table 1 Measured ratios of all specimens included in the analysis (fossil and extant)

\begin{tabular}{|c|c|c|c|c|c|c|c|c|c|}
\hline Measured from source & Figure & Species & Time & 1 & 2 & 3 & 4 & 5 & 6 \\
\hline This publication & $2 \mathrm{~A}$ & Sorellophrynus carbonarius & Carboniferous & 0.77 & 1.27 & - & 1.46 & - & 1.16 \\
\hline This publication & $2 \mathrm{~B}$ & Thelyphrynus elongatus & Carboniferous & 0.80 & 1.83 & 0.96 & 1.06 & 0.55 & 0.61 \\
\hline This publication & $2 \mathrm{C}$ & Weygoldtina scudderi & Carboniferous & 0.88 & 1.54 & 0.65 & 1.30 & 0.34 & 0.69 \\
\hline This publication & $2 \mathrm{D}$ & Weygoldtina scudderi & Carboniferous & - & 1.66 & - & - & - & - \\
\hline This publication & $2 \mathrm{E}$ & Weygoldtina anglica & Carboniferous & 0.95 & 2.16 & - & 1.25 & - & 0.88 \\
\hline This publication & $2 \mathrm{~F}$ & Weygoldtina anglica & Carboniferous & - & 1.17 & - & - & - & - \\
\hline This publication & $2 \mathrm{G}$ & Weygoldtina anglica & Carboniferous & - & 1.54 & - & - & - & - \\
\hline This publication & $2 \mathrm{H}$ & Weygoldtina anglica & Carboniferous & - & 1.55 & - & - & - & - \\
\hline This publication & $2 \mathrm{I}$ & Weygoldtina anglica & Carboniferous & - & 1.45 & - & - & - & - \\
\hline This publication & $2 \mathrm{~J}$ & Sorellophrynus carbonarius & Carboniferous & - & 1.39 & - & - & - & 0.87 \\
\hline This publication & 3 & Weygoldtina anglica & Carboniferous & 0.88 & 1.10 & 0.82 & 0.92 & 0.77 & 0.86 \\
\hline This publication & 5 & Weygoldtina anglica & Carboniferous & 0.71 & 1.60 & 1.00 & 1.47 & 0.44 & 0.64 \\
\hline This publication & 6 & Weygoldtina anglica & Carboniferous & 0.73 & 1.46 & 1.34 & 1.30 & 0.56 & 0.55 \\
\hline This publication & 8 & Weygoldtina anglica & Carboniferous & 0.81 & 1.65 & 1.13 & 1.52 & 0.48 & 0.65 \\
\hline This publication & 10 & Weygoldtina anglica & Carboniferous & 0.79 & - & 1.26 & 1.50 & - & - \\
\hline This publication & $12 \mathrm{~B}$ & Britopygus weygoldti & Cretaceous & - & 1.62 & - & - & 6.33 & 1.37 \\
\hline This publication & 13 & ?Britopygus ?weygoldti & Cretaceous & 0.73 & 1.33 & 1.21 & 1.85 & 0.66 & 1.00 \\
\hline This publication & $14 \mathrm{~A}$ & Kronocharon prendinii & Cretaceous & 0.67 & 1.20 & 2.34 & 1.23 & 1.60 & 0.84 \\
\hline This publication & 14B & Kronocharon prendinii & Cretaceous & 0.80 & 1.58 & 1.32 & 1.39 & 1.03 & 1.09 \\
\hline This publication & $14 \mathrm{C}$ & unnamed & Cretaceous & 0.96 & 1.65 & 0.92 & 0.98 & 0.83 & 0.89 \\
\hline This publication & $14 \mathrm{D}$ & Kronocharon engeli & Cretaceous & 0.87 & 1.87 & 0.94 & 1.60 & 0.63 & 1.07 \\
\hline This publication & $14 \mathrm{E}$ & Kronocharon longicalcaris & Cretaceous & 0.74 & 1.32 & 1.53 & 1.63 & 1.13 & 1.20 \\
\hline This publication & $14 \mathrm{~F}$ & unnamed & Cretaceous & - & 1.28 & - & - & - & 1.23 \\
\hline This publication & $14 \mathrm{G}$ & unnamed & Cretaceous & 0.80 & 1.61 & 0.97 & 1.70 & 0.62 & 1.09 \\
\hline This publication & 15 & Burmacharon dunlopi & Cretaceous & 0.97 & 1.83 & 1.01 & 1.38 & 0.57 & 0.78 \\
\hline This publication & 16 & unnamed & Cretaceous & 0.73 & 1.29 & 1.02 & 1.62 & 0.82 & 1.31 \\
\hline This publication & 18 & Paracharonopsis cambayensis & Eocene & 0.82 & 1.21 & 1.62 & 1.18 & 1.65 & 1.20 \\
\hline This publication & 19B & Phrynus resinae & Miocene & 0.66 & 0.92 & 1.20 & 1.10 & 1.38 & 1.26 \\
\hline This publication & $19 \mathrm{C}$ & Phrynus resinae & Miocene & 0.59 & 1.17 & 1.56 & 0.90 & 1.08 & 0.62 \\
\hline This publication & $20 \mathrm{~A}$ & Phrynus resinae & Miocene & 0.79 & - & 1.28 & 1.20 & - & - \\
\hline This publication & $20 \mathrm{~B}$ & Phrynus sp. & Miocene & 0.78 & 1.46 & 1.25 & 1.12 & 0.80 & 0.72 \\
\hline This publication & $20 \mathrm{D}$ & unnamed & Miocene & 0.61 & 1.48 & 1.71 & 1.51 & 0.96 & 0.85 \\
\hline This publication & $20 \mathrm{E}$ & Phrynus mexicanus & Miocene & 0.92 & 1.64 & 1.11 & 1.57 & 0.98 & 1.38 \\
\hline Weygoldt (1969) & 1 (Female) & Phrynus marginemaculatus & Extant & 0.61 & 1.37 & 2.08 & 1.53 & 1.34 & 0.98 \\
\hline Weygoldt (1969) & 1 (Male) & Phrynus marginemaculatus & Extant & 0.60 & 1.43 & 1.89 & 1.33 & 1.19 & 0.84 \\
\hline de Miranda et al. (2018a) & $2 \mathrm{~A}$ & Weygoldtia davidovi & Extant & 0.72 & 1.56 & 1.49 & 1.47 & 0.90 & 0.89 \\
\hline Weygoldt (1970) & $2 \mathrm{~A}$ & Phrynus marginemaculatus & Extant & 0.85 & 1.91 & 1.00 & 0.90 & 0.48 & 0.43 \\
\hline Weygoldt (1977) & 1 & Trichodamon froesi & Extant & 0.81 & 1.46 & 7.65 & 2.26 & 5.03 & 1.49 \\
\hline de Miranda et al. (2018b) & $13 \mathrm{~A}$ & Trichodamon princeps & Extant & 0.63 & 1.37 & 7.97 & 2.33 & 4.98 & 1.46 \\
\hline de Miranda et al. (2018b) & $13 \mathrm{C}$ & Trichodamon princeps & Extant & 0.71 & 1.40 & 2.72 & 1.81 & 1.75 & 1.16 \\
\hline de Miranda et al. (2018b) & $13 \mathrm{E}$ & Trichodamon princeps & Extant & 0.69 & 1.32 & 7.86 & 2.32 & 4.22 & 1.24 \\
\hline de Miranda et al. (2018b) & $13 \mathrm{~F}$ & Heterophrynus sp. & Extant & 0.82 & 1.81 & 2.69 & 2.41 & 1.76 & 1.57 \\
\hline Prendini et al. (2005) & 2 & Damon gracilis & Extant & 0.64 & 1.17 & 4.92 & 1.76 & 2.85 & 1.02 \\
\hline Prendini et al. (2005) & 3 & Damon annulatipes & Extant & 0.79 & 0.95 & 1.98 & 1.48 & 1.34 & 1.00 \\
\hline Prendini et al. (2005) & 5 & Damon variegatus & Extant & 0.65 & 1.10 & 2.65 & 1.53 & 1.53 & 0.89 \\
\hline Prendini et al. (2005) & 7 & Damon variegatus & Extant & 0.63 & 1.12 & 2.59 & 1.43 & 1.52 & 0.84 \\
\hline Prendini et al. (2005) & 9 & Damon sylviae & Extant & 0.66 & 1.13 & 2.75 & 1.55 & 1.59 & 0.89 \\
\hline Réveillion and Maquart (2015) & 3 (Male) & Charinus sillami & Extant & 0.76 & 1.03 & 2.83 & 1.36 & 2.60 & 1.25 \\
\hline Giupponi and Miranda (2012) & 1 & Sarax curioi & Extant & 0.72 & 1.40 & 1.53 & 1.41 & 0.76 & 0.69 \\
\hline Armas and Arias (2008) & 2 & Phrynus panche & Extant & 0.75 & 1.85 & 1.46 & 1.34 & 0.91 & 0.83 \\
\hline
\end{tabular}


Table 1 (continued)

\begin{tabular}{|c|c|c|c|c|c|c|c|c|c|}
\hline Measured from source & Figure & Species & Time & 1 & 2 & 3 & 4 & 5 & 6 \\
\hline Armas (2014) & 1 & Phrynus pinarensis & Extant & 0.81 & 1.60 & 1.53 & 1.74 & 1.01 & 1.15 \\
\hline Maquart et al. (2016) & 1 (Female) & Phrynichus exophthalmus & Extant & 0.80 & 1.60 & 3.91 & 1.64 & 2.37 & 0.99 \\
\hline Prous et al. (2017) & $2 \mathrm{~B}$ & Heterophrynus longicornis & Extant & 0.78 & 1.87 & 2.24 & 2.34 & 1.06 & 1.11 \\
\hline Viquez et al. (2014) & 3 & Heterophrynus armiger & Extant & 0.76 & 1.88 & 2.25 & 2.75 & 1.22 & 1.49 \\
\hline Teruel and Questel (2011) & $2 \mathrm{~A}$ & Charinus bruneti & Extant & 0.68 & 1.13 & 1.10 & 1.45 & 0.78 & 1.03 \\
\hline Kury et al. (2010) & $2 \mathrm{~A}$ & Heterophrynus longicornis & Extant & 0.74 & 1.78 & 3.63 & 2.99 & 2.14 & 1.76 \\
\hline Réveillion and Maquart (2018) & $2 \mathrm{~A}$ & Charon ambreae & Extant & 0.75 & 1.44 & 5.62 & 1.75 & 3.89 & 1.21 \\
\hline Rahmadi and Harvey (2008) & 1 & Stygophrynus sunda & Extant & 0.83 & 1.42 & 1.83 & 1.69 & 1.27 & 1.17 \\
\hline Cokendolpher and Sissom (2001) & 5 & Paraphrynus grubbsi & Extant & 0.82 & 1.66 & 1.78 & 2.59 & 1.27 & 1.86 \\
\hline Seiter and Hörweg (2013) & 3 & Charinus ioanniticus & Extant & 0.80 & 1.45 & 1.78 & 1.54 & 1.20 & 1.04 \\
\hline El-Hennawy (2002) & 1 & Charinus ioanniticus & Extant & 0.63 & 1.22 & 1.74 & 1.71 & 1.11 & 1.09 \\
\hline Teruel and Armas (2005) & $1 \mathrm{~F}$ & Phrynus decoratus & Extant & 0.73 & 1.44 & 1.35 & 1.44 & 0.91 & 0.96 \\
\hline do Monte et al. (2015) & $4 b$ & Charinus eleonorae & Extant & 0.73 & 1.95 & 1.97 & 2.30 & 0.99 & 1.16 \\
\hline Torres-Contreras et al. (2015) & $1 \mathrm{~B}$ & Phrynus barbadensis & Extant & 0.61 & 1.31 & 1.70 & 1.20 & 1.16 & 0.82 \\
\hline Teruel and Questel (2015) & $1 \mathrm{a}$ & Charinus desirade & Extant & 0.83 & 1.83 & 1.12 & 1.28 & 0.62 & 0.71 \\
\hline Teruel and Questel (2015) & $2 \mathrm{a}$ & Charinus desirade & Extant & 0.80 & 1.89 & 1.18 & 1.24 & 0.61 & 0.64 \\
\hline Garwood et al. (2017) & 2 & Paracharon caecus & Extant & 1.05 & 1.94 & 1.88 & 0.82 & 1.18 & 0.5 \\
\hline
\end{tabular}

1 ratio shield length: shield width, 2 ratio trunk length: trunk width, 3 ratio pedipalp (without distal claw): shield length, 4 ratio leg length: shield length, 5 ratio pedipalp (without distal claw): trunk length, 6 ratio leg length: trunk length
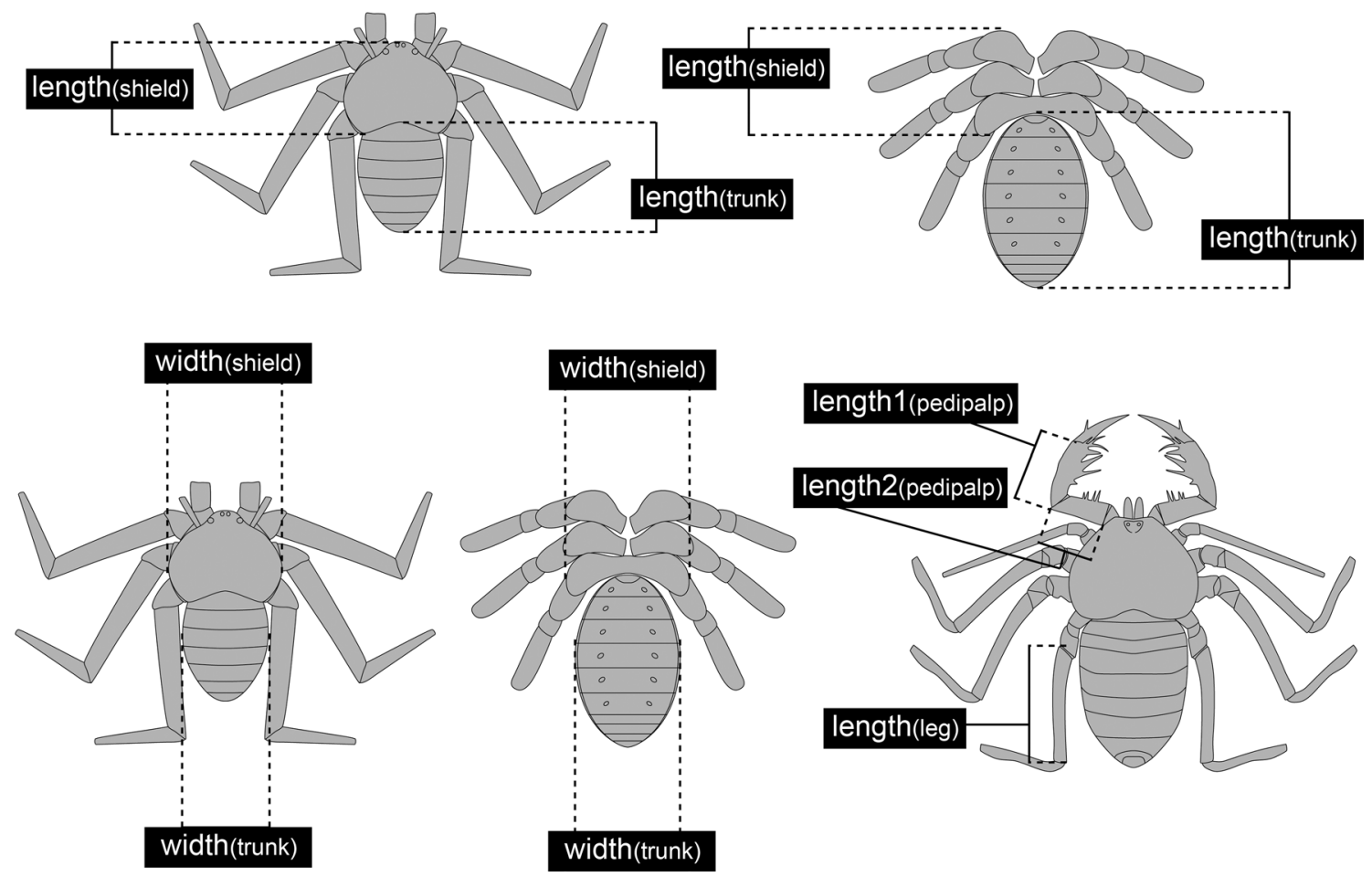

Fig. 1 Measurements of the different body parts of the whip spiders

only called shield), length and width of the trunk (opisthosoma), length of the proximal part of the pedipalp (excluding the distal claw), and length of the first longer element of the best preserved locomotory appendage (femur). 
In specimens in which the shield was not preserved, we estimated the dimensions based on the proximal parts of the locomotory appendages (basipods in terminology of Euarthropoda, usually termed coxae in literature on Arachnida). While this is only a rough estimation, it allows us to include significantly more specimens. This may make our conclusion less sharp, but nevertheless will provide a wider picture.

\section{Results}

(1) The oldest supposed fossil of Amblypygi is a piece of cuticle and was formally named Ecchosis pulchribothrium (Selden et al. 1991). It was interpreted as possessing trichobothria on the patella, a character only known in modern whip spiders. The specimen is not informative for the structures measured herein and is therefore not further considered.

(2) Scudder (1876) reported a fossil remain (no. 3085, Museum of McGill College) from the Carboniferous Cape Brenton deposit and interpreted it as an isolated abdomen of a dragonfly larva. It was later re-interpreted as a remain of a whip spider (Scudder 1890). Yet, already Pocock (1911) questioned this interpretation, a view supported by Dunlop (2018). The specimen is considered lost, and based on the original report, a more reliable interpretation is impossible.
This specimen is, therefore, not further considered here.

(3) The species Sorellophrynus carbonarius (originally Protophrynus carbonarius) is represented by one specimen, UMMP 7220 (Museum of Paleontology of the University of Michigan, number according to Dunlop 2018), from the Mazon Creek Lagerstätte (Fig. 2a; Petrunkevitch 1913: text-figs. 32, 33, plate VI, figs. 30, 31; Dunlop 2018: fig. 4A, B). The specimen has shield and trunk well preserved. The proximal regions of the pedipalps are apparent. There are possible indications of the more proximal region of the feeler legs. The more proximal regions of the locomotory appendages are well recognisable, also some more distal parts. Dunlop (2018) discussed the possibility that the specimen is a juvenile representative of another species from the Carboniferous, yet concludes this possibility as unlikely. The specimen was considered lost since at least 2008 (Dunlop 2018).

(4) The species Thelyphrynus elongatus is, likewise, represented by a single specimen, UMMP 7222 (Museum of Paleontology of the University of Michigan, number according to Dunlop 2018), from the Mazon Creek Lagerstätte (Fig. 2b; Petrunkevitch 1913: textfigs. 27, 28, plate V, fig. 26; Dunlop 2018: fig. 4C). The shield is less clearly preserved, the trunk appears quite elongate. Pedipalps are better preserved, but do
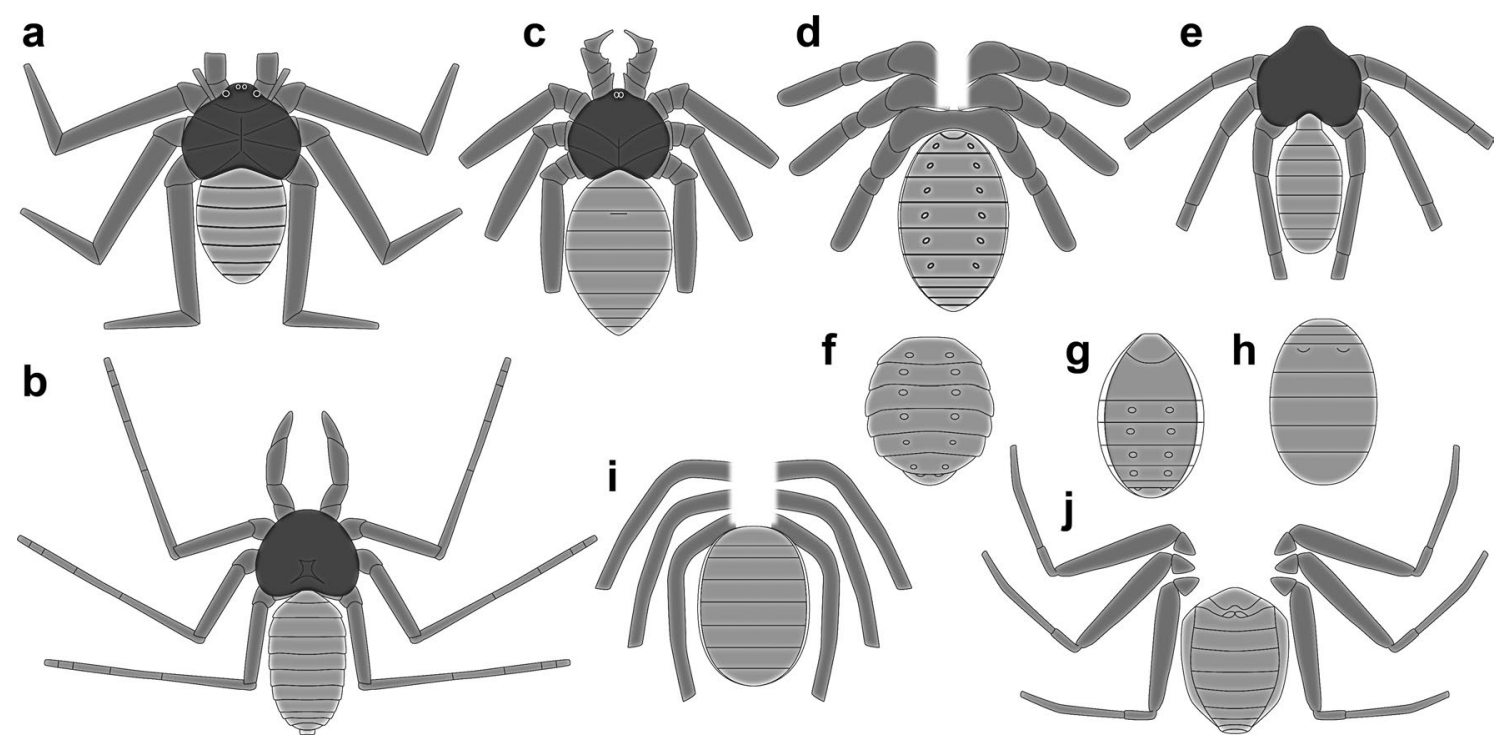

Fig. 2 Simplified representations of Carboniferous whip spiders from the literature. a-d From Mazon Creek, USA. a Sorellophrynus carbonarius, UMMP 7220, holotype (based on Petrunkevitch 1913: combined from text-figs. 32, 33). b Thelyphrynus elongatus, UMMP 7222, holotype (based on Petrunkevitch 1913: combined from textfigs. 27, 28). c, d Weygoldtina scudderi. c USNM 37969, holotype (based on Petrunkevitch 1913: combined from text-figs. 29, 30). d USNM 37964 (based on Petrunkevitch 1913: text-fig. 31). e-i Brit- ish Coal Measures; Weygoldtina anglica. e BMNH In31260 (based on Dunlop et al. 2007a: fig. 4c). f BMNH In 22836 (based on Dunlop et al. 2007a: fig. 5e). g BMNH I 13872 (based on Dunlop et al. 2007a: fig. 5c). h BMNH I 7892 (based on Dunlop et al. 2007a: fig. 5a). i BMNH I 7905 (based on Dunlop et al. 2007a: fig. 5b). j Sorellophrynus carbonarius, MM LL 11000, Writhlington Geological Nature Reserve (based on Dunlop 1994: fig. 4) 
not show clear spination. Also locomotory appendages are quite well preserved, including some of the more distal parts. Dunlop (2018) discussed the specimen critically, but concluded that the interpretation as a representative of Amblypygi is well founded. The specimen was considered lost since at least 2008 (Dunlop 2018).

(5) Specimen USNM (Smithsonian National Museum of Natural History) 37969 (Fig. 2c; Petrunkevitch 1913: text-figs. 29, 30, plate V, figs. 27, 28; Dunlop 2018: fig. 3) also comes from the Mazon Creek Lagerstätte. The specimen is the holotype of the species Weygoldtina scudderi (originally Graephonus scudderi or Graephonus carbonarius as the first name was mostly overlooked; see Dunlop 2018). The specimen appears quite complete, including shield, trunk, parts of pedipalps and locomotory appendages.

(6) Specimen USNM 37964 (Fig. 2d; Petrunkevitch 1913: text-fig. 31, plate V, fig. 29) was considered to represent an additional specimen of Weygoldtina scudderi. The specimen mainly preserves the trunk and part of the locomotory appendages. Still, based on the available characters, Dunlop (2018) tentatively accepted the interpretation of Petrunkevitch (1913).

(7) Specimen BMNH (British Museum of Natural History, NHM London) In31260 (Fig. 2e) comes from the British Coal Measures (Carboniferous) and has been interpreted as a representative of Weygoldtina anglica (originally Graephonus anglicus; also depicted in Pocock 1911: plate I, fig. 4). The specimen has a well-preserved shield and trunk (Dunlop et al. 2007a: fig. 4c, d). Also parts of the posterior locomotory appendages are preserved close to the trunk. The figure in Dunlop et al. (2007a) states two different repository numbers, BMNH In 31260 for their fig. 4c, and BMNH In 31620 for their fig. 4d. In the text, both figures are referred to as BMNH In 31260. It seems, therefore, that these are part and counterpart of one specimen.

(8) Specimen BMNH In 22836 (Fig. 2f) is an isolated trunk from the British Coal Measures. It was interpreted as a representative of Weygoldtina anglica by Dunlop et al. (2007a: fig. 5e).

(9) Specimen BMNH I 13872 (Fig. 2g) is also an isolated trunk from the British Coal Measures. It was interpreted as a representative of Weygoldtina anglica by Dunlop et al. (2007a: fig. 5c).

(10) Specimen BMNH I 7892 (Fig. 2h) is also an isolated trunk from the British Coal Measures. It was interpreted as a representative of Weygoldtina anglica by Dunlop et al. (2007a: fig. 5a).

(11) Specimen BMNH I 7905 (Fig. 2i) is, also, an isolated trunk, with some remains of the locomotory append- ages, from the British Coal Measures. It was interpreted as a representative of Weygoldtina anglica by Dunlop et al. (2007a: fig. 5b).

(12) Specimen MM (Manchester Museum) LL 11000 (Fig. 2j) comes from the Writhlington Geological Nature Reserve (Carboniferous). The specimen has a preserved trunk and parts of the locomotory appendages (Dunlop 1994: figs. 3, 4). While the specimen is incomplete, Dunlop (1994) argued that the specimen is a representative of Sorellophrynus carbonarius; this was further supported by Dunlop (2018).

(13) Specimen BMNH In 31233 (Figs. 3, 4) is the holotype of Weygoldtina anglica. It is preserved as part and counterpart (Dunlop et al. 2007a: figs. 1a, b, 2a, b; part also depicted in Pocock 1911: plate I, fig. 4a). The specimen has the shield and trunk preserved as well as some aspects of the appendages. The shield possesses an apparent elevation where the eyes are situated. The trunk segments are apparent by individual dorsal sclerites (tergites). The pedipalps extend forward; the here-applied contrasting methods reveal clearly two prominent spines on each pedipalp, not recognisable before (e.g. Dunlop et al. 2007a); pedipalps appear to be oriented with the evolutionary medially part downwards. The locomotory appendages are well preserved on the right side of the body. Of the left side, only the more distal part of probably the last locomotory appendage is preserved. The very distal distal part is adjacent to the trunk end and appears to have been interpreted as part of the trunk end before (Dunlop et al. 2007a).

(14) Specimen BMNH I 13877 (Fig. 5) is a (non-type) representative of Weygoldtina anglica. It is preserved as part and counterpart (part depicted in Dunlop et al. 2007a: fig. 5d). Shield and part of the trunk available in dorsal view, trunk complete in ventral view. Chelicerae apparent, as are proximal parts of the pedipalps in dorsal view; more distal parts in ventral view; also one spine in rather lateral orientation apparent. Pedipalps appear almost parallel to each other, only a slight inclination is apparent. More proximal parts of all locomotory appendages preserved.

(15) Specimen BMNH In 31234 (Figs. 6, 7) is a representative of Weygoldtina anglica. It is preserved as part and counterpart (Dunlop et al. 2007a: figs. 1c, d, 2c, d; also depicted in Pocock 1911: plate I: fig. 4c). The specimen is very well preserved, even exhibiting the feeler-type appendage. The specimen has been threedimensionally reconstructed based on $\mu \mathrm{CT}$ scanning (Garwood et al. 2017). Also light-based documentation reveals numerous details of the shield shape and the appendages. The pedipalps appear stronger inclined against each other, forming about a $90^{\circ}$ angle 


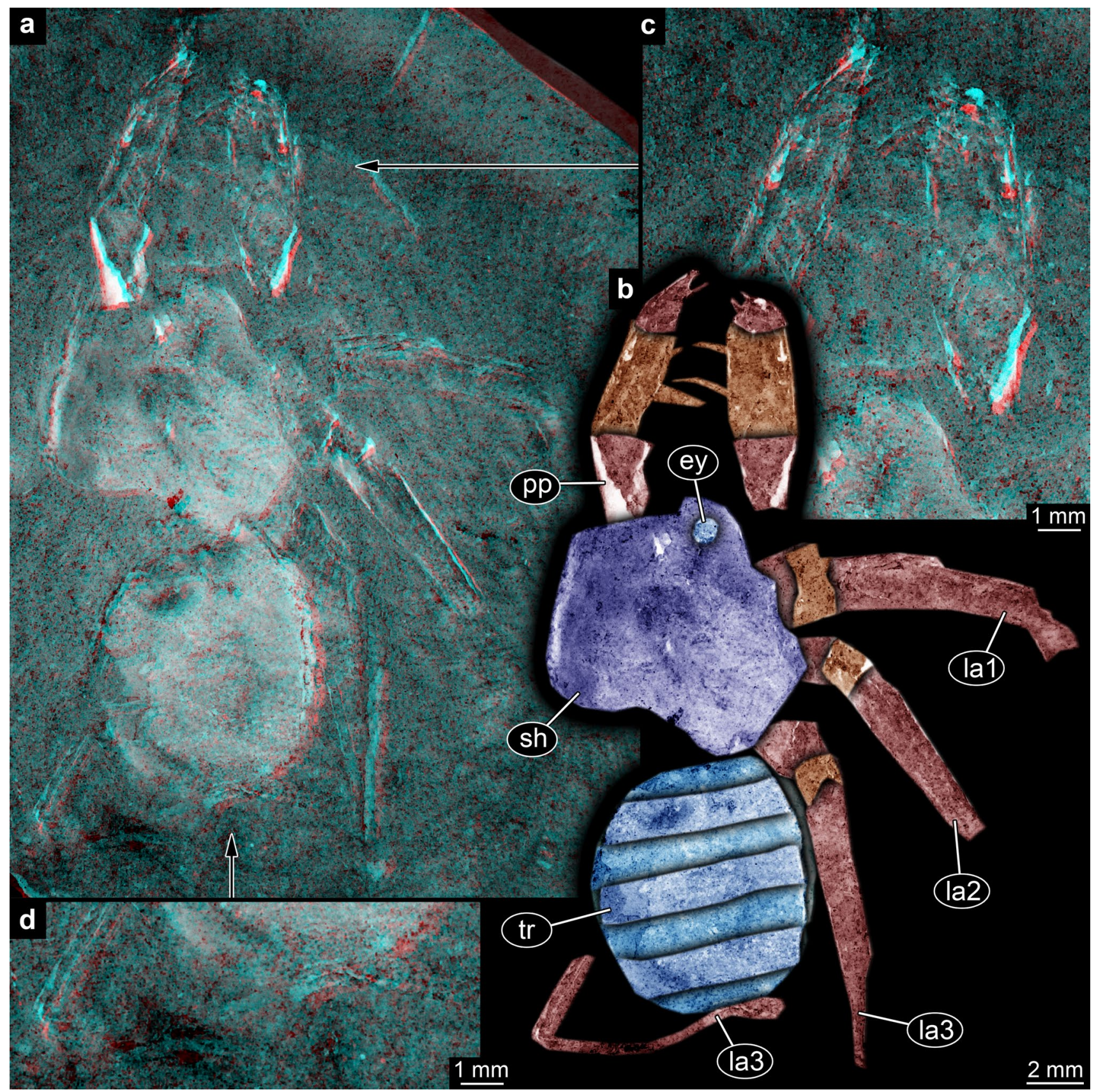

Fig. 3 Whip spider from the British Coal Measures, Weygoldtina anglica, BMNH In 31233, holotype, part. a Overview in dorsal view; arrow points to area magnified in d. b Colour-marked version of a. $\mathbf{c}$ Close-up on pedipalps. d Close-up on trunk end; note the appendage touching the terminal end. a, c, $\mathbf{d}$ Stereo image (please use red-cyan glasses to view). ey eyes, lal-3 locomotory appendage 1-3, pp pedipalp, sh shield, $t r$ trunk

b, there erroneously 31236; also depicted in Pocock 1911: plate I, fig. 4b). Also this specimen is preserved with many details. Shield shape and body outline are very well apparent. Chelicerae are present. Pedipalps show well-preserved spines (Fig. 8d). Pedipalps are only weakly inclined against each other (Fig. 9a).

Prominent windows of the proximal elements are well apparent. The anterior spines (usually called 


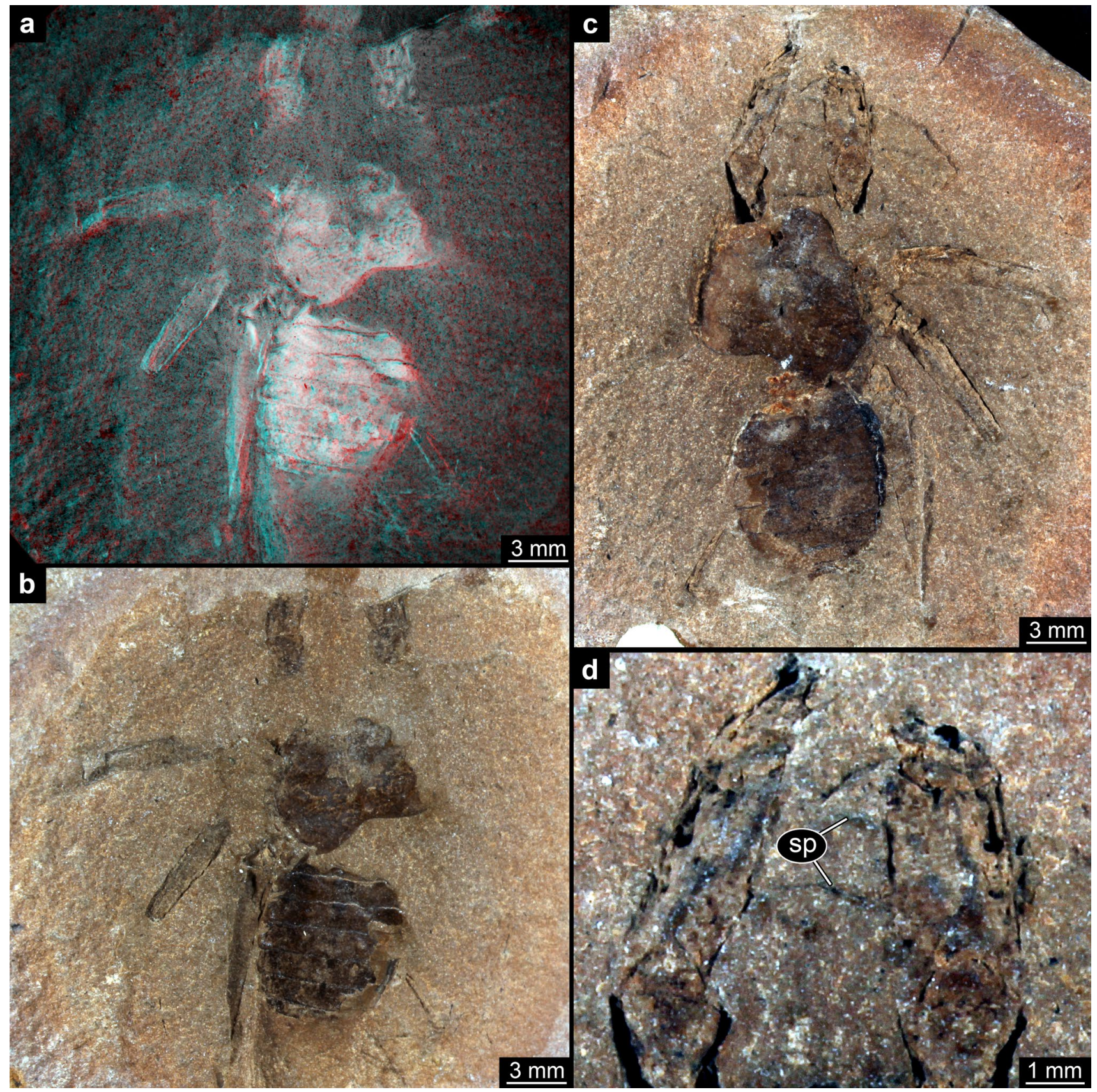

Fig. 4 Whip spider from the British Coal Measures, Weygoldtina anglica, BMNH In 31233, holotype, continued. a, b Counterpart. a Overview, stereo image (please use red-cyan glasses to view). b Overview. c, d Part. c Overview. d Close-up on pedipalps. $s p$ spine

dorsal spines, but see "Discussion" below) of the pedipalps are almost horizontally positioned. Also the locomotory appendages are well preserved. The proximal element (basiopod in euarthropodan terminology, coxa in literature on Arachnida) of locomotory appendage 1 bears numerous massive short spines (Fig. 9c, d). Indications of such spines are also apparent in the CT scans of BMNH In 31234 (Garwood et al. 2017: fig. 1b). Endopod elements 3 and 4 can be recognised as separate units, but seem to not form a functional joint (see also Garwood et al. 2017 for specimen BMNH In 31234).

(17) Specimen BMNH In 31257 (Figs. 10, 11) is a representative of Weygoldtina anglica. It is preserved as part and counterpart (Dunlop et al. 2007a: fig. 5f). The specimen is difficult to understand on a first view, yet the stereo images reveal that it is preserved in an antero-dorsal orientation; hence, we look into the 


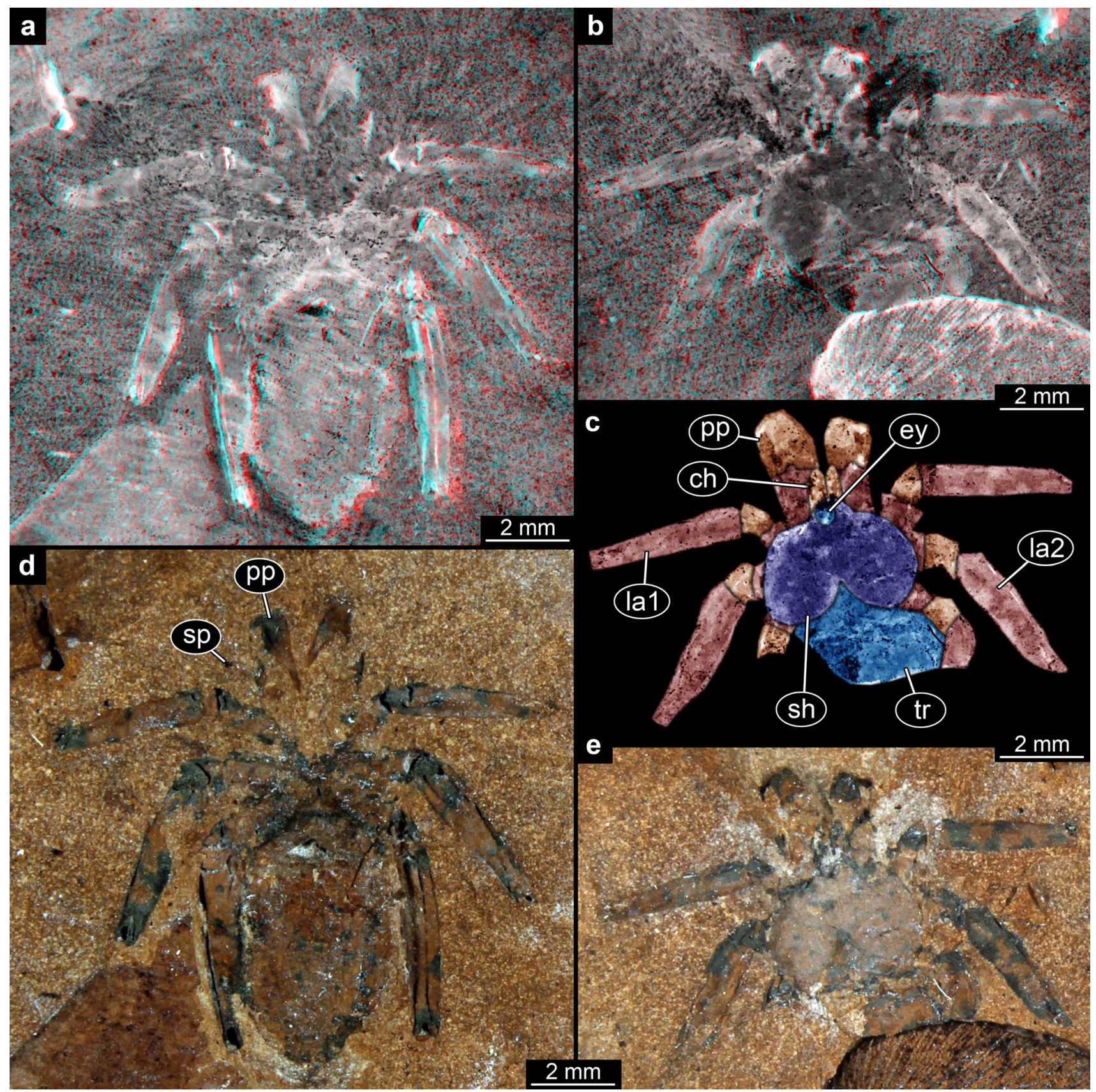

Fig. 5 Whip spider from the British Coal Measures, Weygoldtina anglica, BMNH I 13877. a, b Stereo images (please use red-cyan glasses to view). a Part. b Counterpart. c Colour-marked version of b. d, e Overviews. d Part; note posterior (ventral) spine. e Counterpart. ch chelicera, ey eyes, lal-2 locomotory appendage 1-2, pp pedipalp, $s h$ shield, $s p$ spine, $t r$ trunk face of the animal. Shield, chelicerae, pedipalps, and proximal parts of the locomotory appendages are well preserved. The pedipalps are only weakly inclined, the anterior spines are oriented more or less horizontally (Figs. 10c, 11b).

(18) Another possible specimen of Weygoldtina anglica was depicted by Pocock (1911: plate I, fig. 4d). The drawing shows an isolated shield. It is unclear if the specimen only represents that shield or whether only the shield is drawn from a more completely preserved specimen. The drawing also appears highly idealised. Pocock (1911) does not mention any repository number. The specimen is not mentioned in any further 


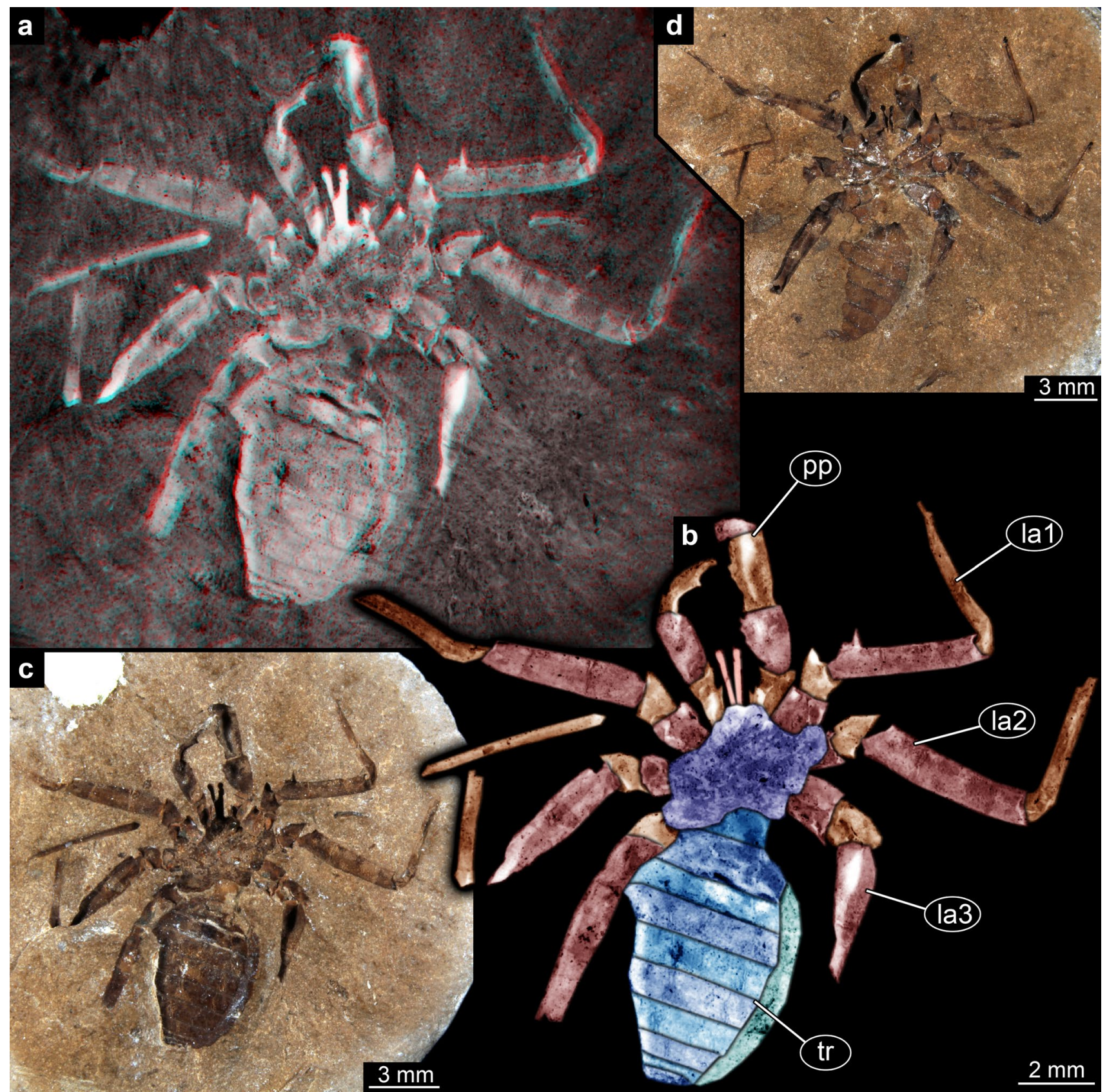

Fig. 6 Whip spider from the British Coal Measures, Weygoldtina anglica, BMNH In 31234. a-c Part. a Stereo image (please use red-cyan glasses to view). b Colour-marked version of a. c Overview. d Counterpart, overview. lal-3 locomotory appendage 1-3, $p p$ pedipalp, $t r$ trunk

publication. Due to these uncertainties, we do not consider the specimen further here.

(19) Specimen SMNS 64332 (Fig. 12a) is the holotype of Britopygus weygoldti (Dunlop and Martill 2001: figs. 1a, 2a). The specimen originated from the 110 million years old Crato Formation, Brazil. The specimen is preserved in ventral view, providing details of the chelicera, pedipalps, locomotory appendages and sternum.

(20) Another whip spider from the Crato Formation, a presumed representative of the group Phrynichidae, was mentioned by Giupponi and Baptista (2003) in a conference abstract. However, the specimen was not accessible for our study and no further information is 


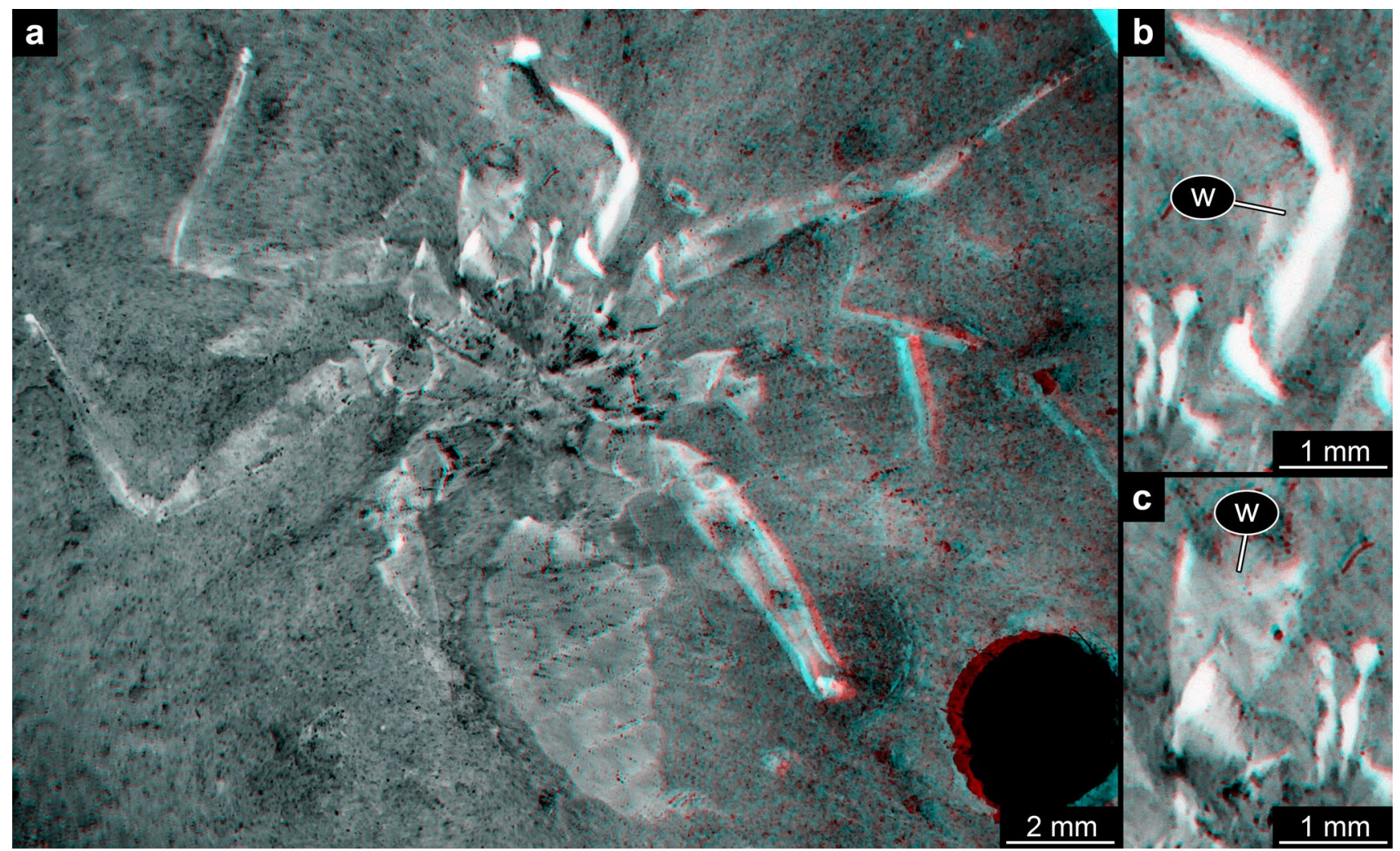

Fig. 7 Whip spider from the British Coal Measures, Weygoldtina anglica, BMNH In 31234, continued, counterpart. a Overview, revealing ventral details. b, c Details of pedipalps. b Left pedipalp. $\mathbf{c}$ Right pedipalp. All stereo images (please use red-cyan glasses to view). $w$ window

available; hence, it is not considered for further analyses.

(21) Specimen SMNS 66123 (Fig. 12b) was interpreted as a second representative of Britopygus weygoldti (Dunlop and Barov 2005: figs. 1-8); the specimen also comes from the Crato Formation. The specimen is preserved in ventral view, with most of the trunk, remains of two locomotory appendages and especially a very long and prominent pedipalp preserved (Fig. 12b). As the pedipalps are very different from the other known specimen, we need to assume that the two specimens either represent different genders or growth stages of the same species. The specimen was refigured in Dunlop et al. (2007b: 126, figs. 9, 10) as a photograph and as interpretive drawing.

(22) Another specimen from the Crato Formation was mentioned by dos Santos Silva (2017) in his Master thesis. The specimen was presumed to be a representative of the group Charinidae but cannot be considered here as no further information is available to us.

(23) A new specimen from the Sennlaub collection (Fig. 13) also comes from the Crato Formation. We therefore assume that it could also be a representative of Britopygus weygoldti. The comparison is not sim- ple as both already known specimens of the species are only known in ventral aspect, the new specimen is preserved in dorsal aspect. This is the first specimen preserving the shield. Also the trunk is well preserved, including the smaller terminal segments (pygidium). Additionally, rather long locomotory appendages and pedipalps are preserved. The pedipalps are rather short, comparable to the condition in the holotype.

(24) Specimen JZC Bu150 (Fig. 14a) is preserved in Cretaceous, 100 million-year-old amber from Myanmar. It is the holotype of the species Kronocharon prendinii (Engel and Grimaldi 2014: figs. 3-6). The specimen is exceptional in being preserved with several immatures (also called nymphs).

(25) A supposedly second specimen (Fig. 14b) of Kronocharon prendinii was reported by Selden and Ren (2017: fig. 3), also figured in Zhang (2017: figs. on pp. 82-83). The specimen is also preserved in amber from Myanmar.

(26) An unnamed specimen (Fig. 14c) was depicted in Xia et al. (2015: upper fig. on p. 169). The specimen is also preserved in amber from Myanmar. The specimen has an anterior protruding shield similar to the shield of representatives of Palaeoamblypygi (see 


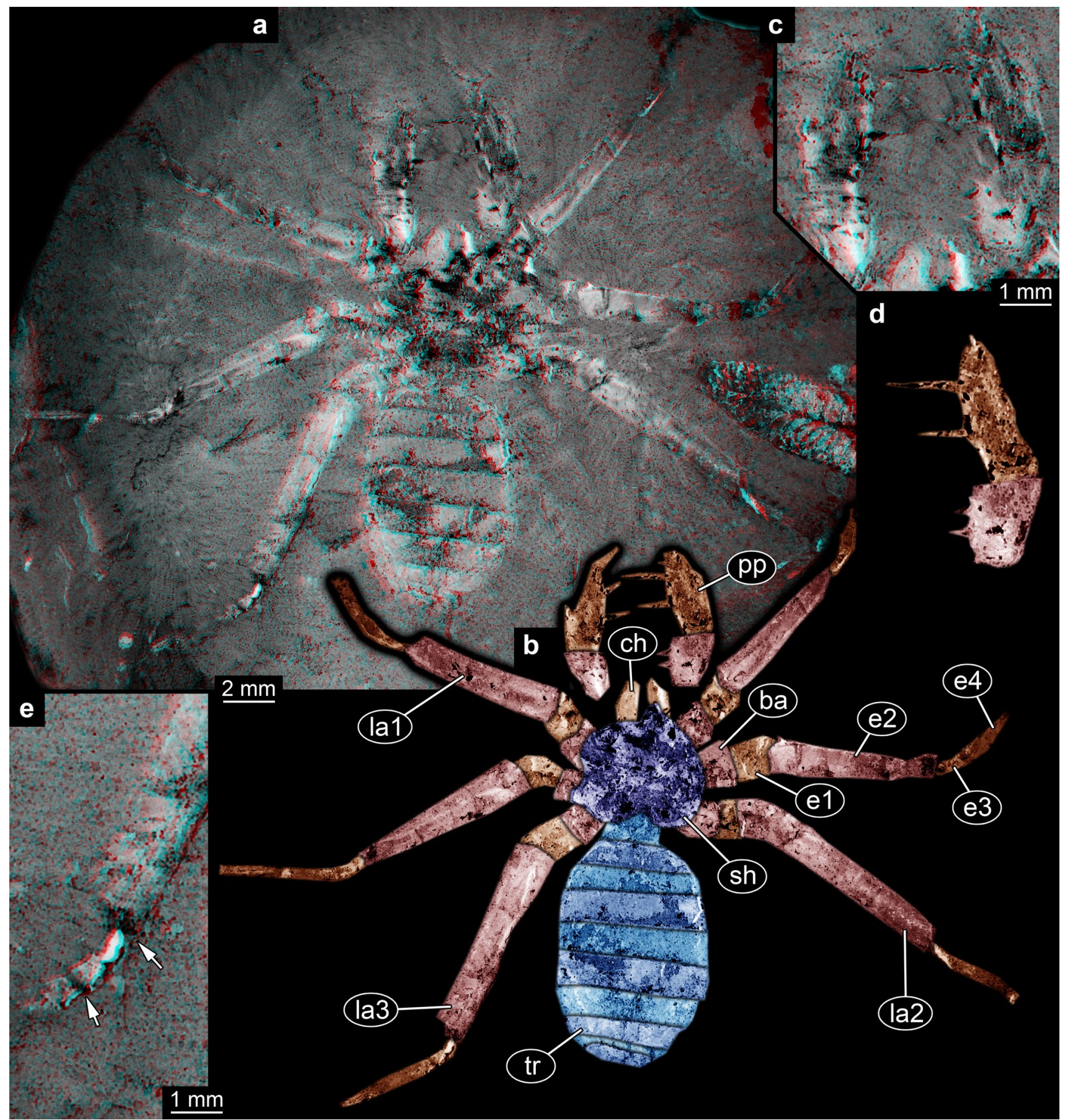

Fig. 8 Whip spider from the British Coal Measures, Weygoldtina anglica, BMNH In 31248, part. a Overview. b Colour-marked version of a. c Close-up on pedipalps. d Colour-marked detail of c. e Detail of locomotory appendage; arrows mark separation of endopod elements 3 and 4. a, c, e Stereo images (please use red-cyan glasses to view). $b a$ basipod (coxa), ch chelicera, e1-4 endopod elements 1-4, lal-3 locomotory appendage 1-3, pp pedipalp, sh shield, $t r$ trunk

(27) A specimen from the Wunderlich collection (Fig. 14d) was named Kronocharon engeli by Wunderlich (2015: figs. 183, 184). The specimen is also preserved in amber from Myanmar. The specimen provides a 


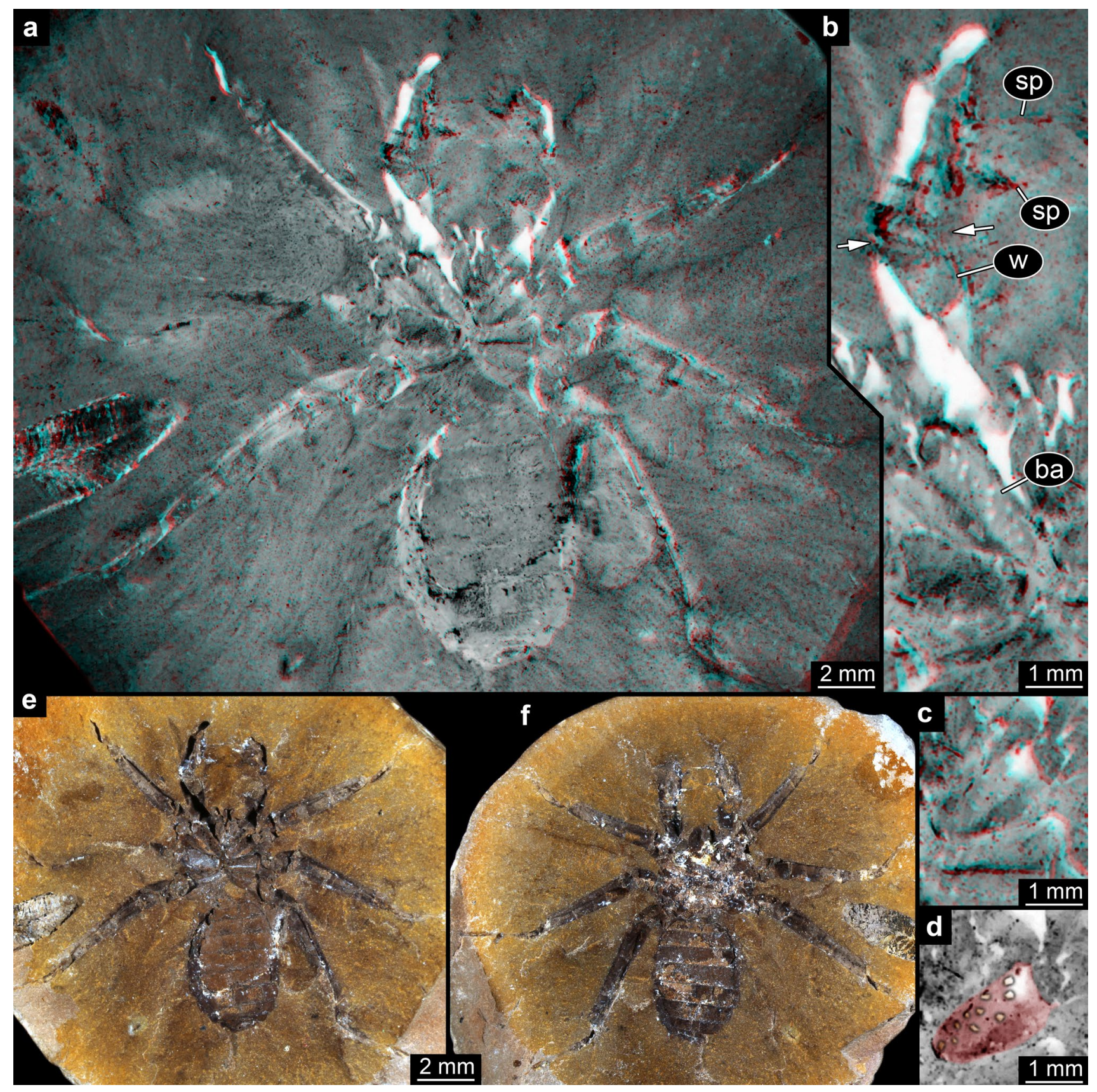

Fig. 9 Whip spider from the British Coal Measures, Weygoldtina anglica, BMNH In 31248, continued. a-e Counterpart. a-c Stereo images (please use red-cyan glasses to view). a Overview, revealing ventral details. b Close-up on right pedipalp; arrows mark pivot

good impression of the overall morphology, including details of the pedipalps.

(28) A specimen from the Wunderlich collection (Fig. 14e) was named Kronocharon longicalcaris by Wunderlich (2015: figs. 185, 186). The specimen is also preserved in amber from Myanmar. The specimen provides a good impression of the overall morphology, including details of the pedipalps. joints. c Close-up on basipod of left pedipalp. d Colour-marked version of c; basipod main portion in red, spines in orange. e Overview. f Part, overview

(29) Another unnamed specimen (Fig. 14f) was depicted in Xia et al. (2015: lower fig. on p. 169). The specimen is also preserved in amber from Myanmar. Most details of the specimen are largely concealed, only trunk and locomotory appendages are apparent.

(30) Specimen 11095 from the collection Gröhn (Fig. 14g) was depicted in Gröhn (2015: fig. 11095 on p. 131). The specimen is also preserved in amber from Myan- 


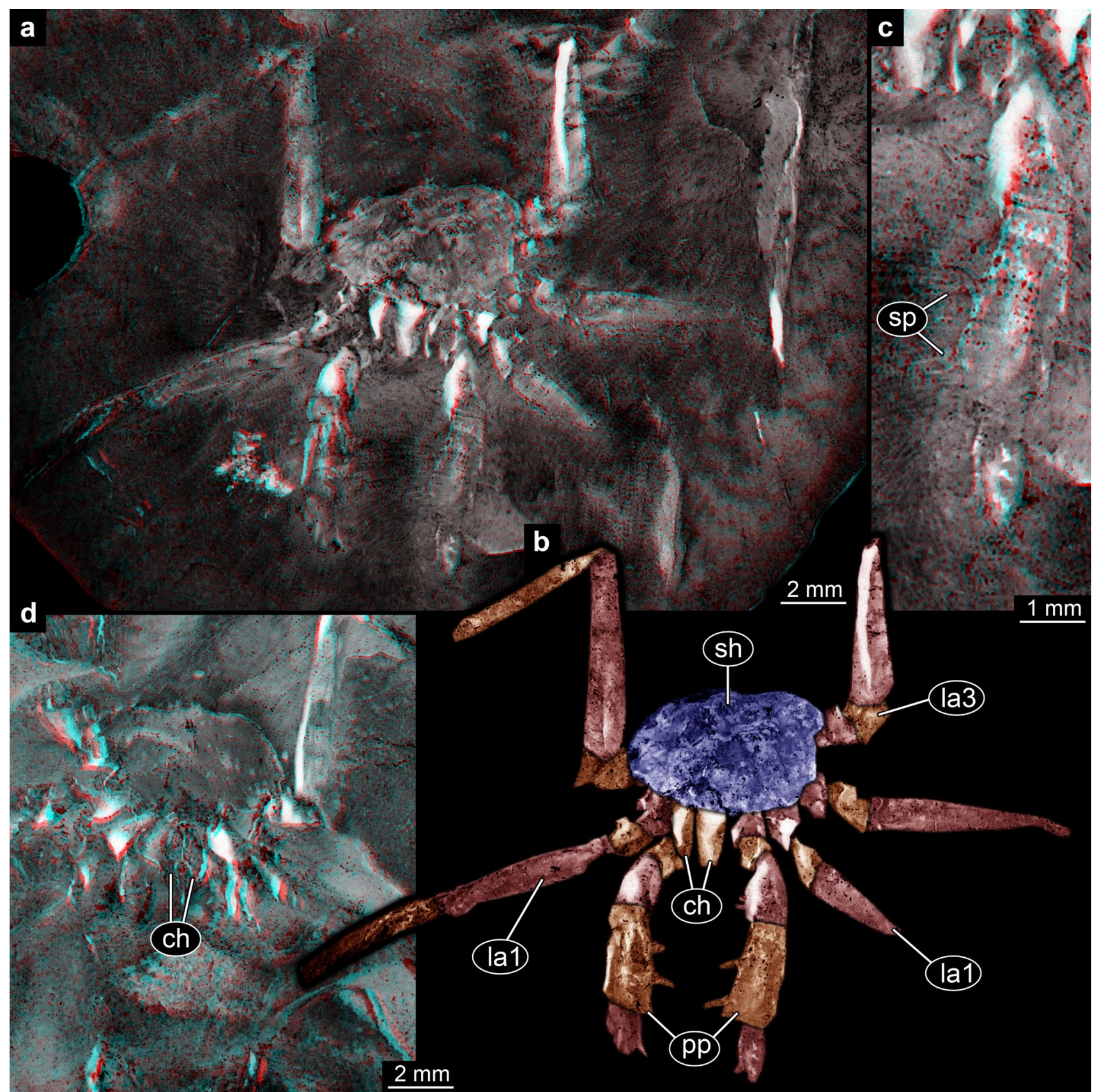

Fig. 10 Whip spider from the British Coal Measures, Weygoldtina anglica, BMNH In 31257. a-c Part. a Overview. b Colour-marked version of a. c Close-up on pedipalps. d Counterpart, close-up on anterior region, depth inverted. a, c, $\mathbf{d}$ Stereo images (please use redcyan glasses to view). ch chelicera, la1-3 locomotory appendage 1-3, $p p$ pedipalp, $s h$ shield, $s p$ spine mar. It provides a good impression of the overall morphology, including details of the pedipalps.

(31) Specimen NIGP173207 (Fig. 15) is the holotype and only known representative of Burmacharon dunlopi, another whip spider from amber from Myanmar (Hu et al. 2020). The overall morphology of the specimen is well accessible in dorsal and ventral view (Hu et al. 2020: fig. 1). Additionally, Hu et al. (2020) provide detail images (photos and drawings) of the prosoma in dorsal (fig. 2A, B) and ventral view (fig. 2C, D) as well as of the pedipalp (fig. 3) and of a walking appendage (fig. 4).

(32) A here newly reported specimen PED 0099 (Figs. 16, 17 ) is also preserved in amber from Myanmar. In dorsal view (Fig. 16a, b), the shape of the shield is well apparent. It appears that another organism has 


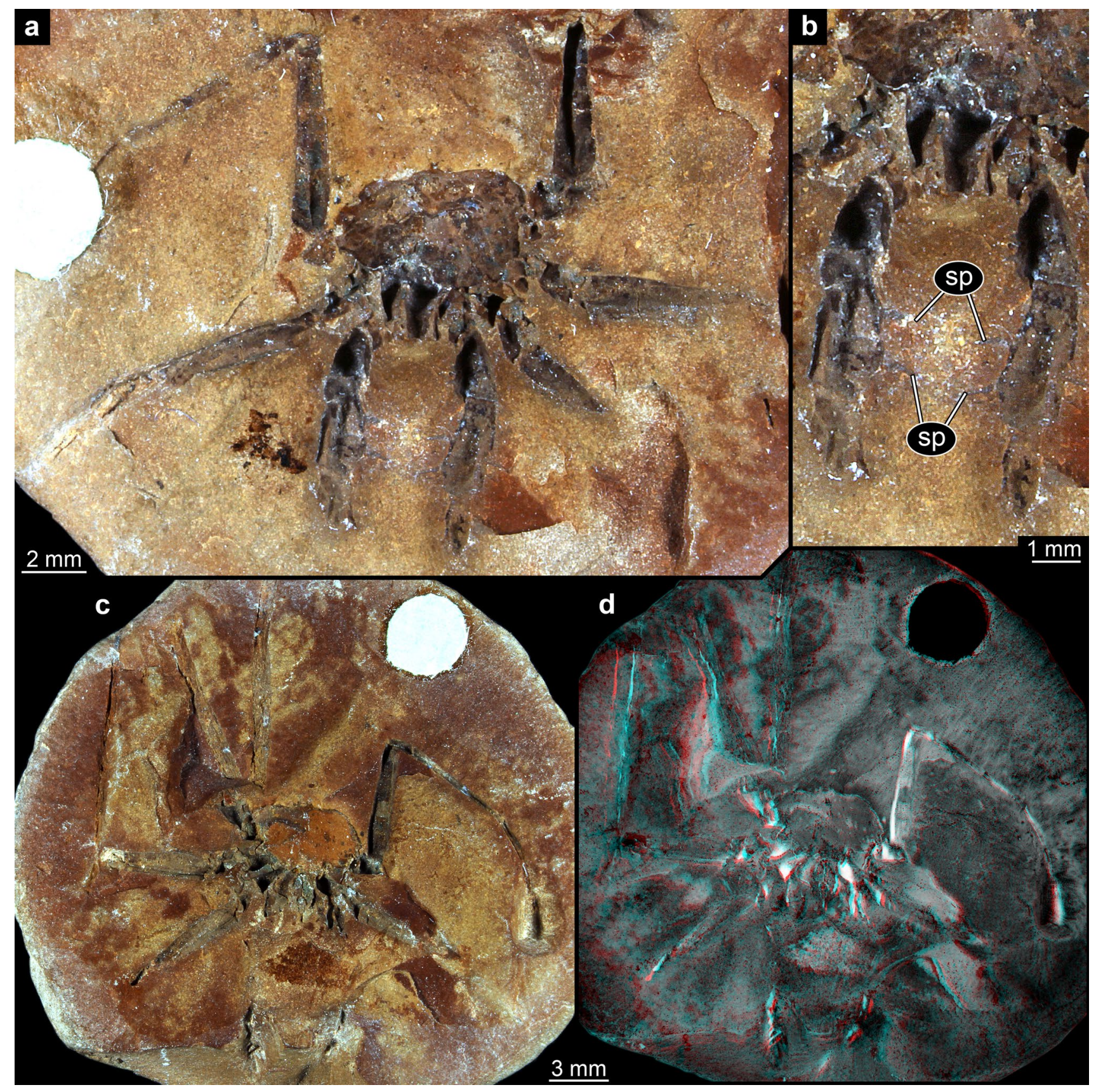

Fig. 11 Whip spider from the British Coal Measures, Weygoldtina anglica, BMNH In 31257, continued. a, b Part. a Overview. b Close-up on pedipalps. c, d Counterpart. c Overview. d Stereo image (please use red-cyan glasses to view)

bitten off a piece from the anterior region, leaving part of the right side of the shield and the right pedipalp. The pedipalps appear to be highly foldable and have a horizontal plane of action (Fig. 16c). In ventral view (Fig. 17a, b), the subdivision of the trunk is well apparent.

(33) Specimen Tad 456 (Fig. 18) is the holotype and only known specimen of the species Paracharonopsis cambayensis (Engel and Grimaldi 2014: figs. 1, 2).
The specimen is preserved in Eocene Indian Cambay amber. It is so far the only specimen from Eocene deposits. Preservation (and also documentation) is exceptionally good. Most details of the morphology can be accessed.

(34) Specimen UCMP B-7043-22, sp-no. 13545 (Fig. 19a) was named Electrophrynus mirus by Petrunkevitch (1971). The specimen is preserved in Miocene Mexican Chiapas amber (15-20 mya). Dunlop and Mru- 
Fig. 12 Simplified representations of whip spiders from the Crato Formation, Britopygus weygoldti. a SMNS 64332 (based on Dunlop and Martill 2001). b SMNS 66123 (based on Dunlop and Barov 2005)

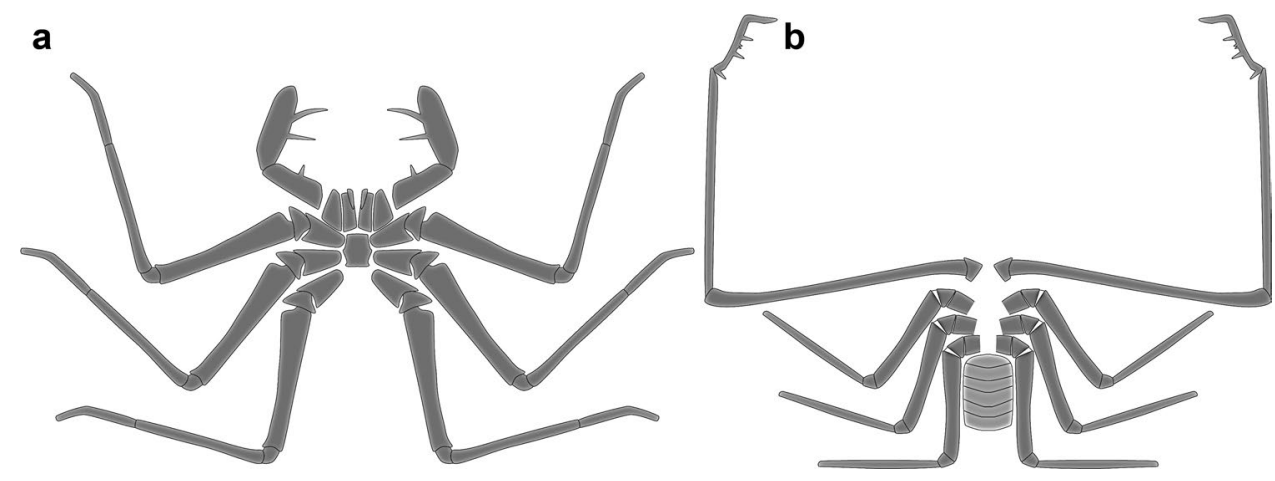

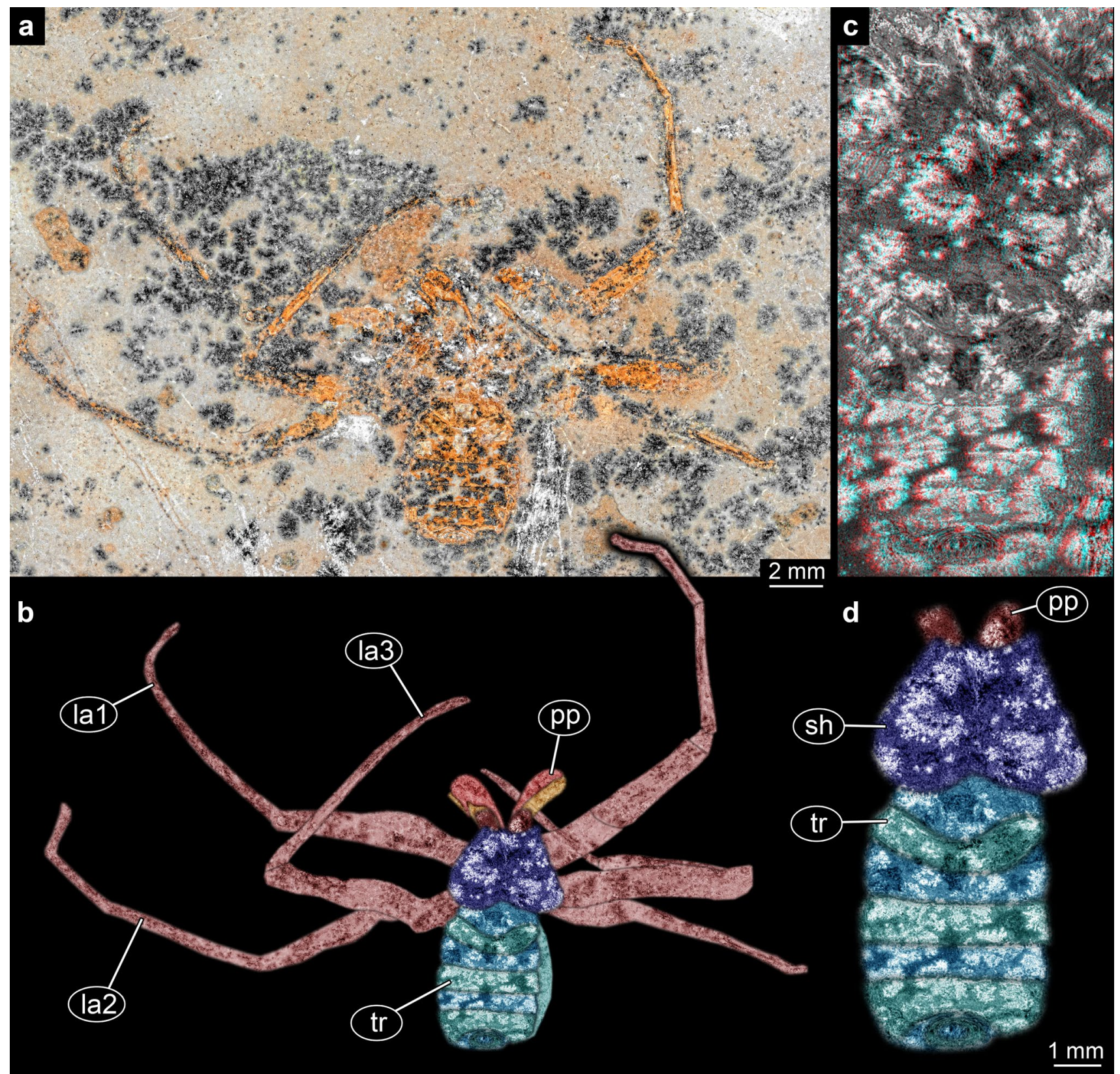

Fig. 13 New whip spider specimen from the Crato Formation, collection Sennlaub. a Overview. b Colour-marked version of a. c Stereo image (please use red-cyan glasses to view) of central region. $\mathbf{d}$ Colour-marked version of c 
Fig. 14 Simplified representations of whip spiders from amber from Myanmar. a, b Kronocharon prendinii. a JZC Bu150 (based on Engel and Grimaldi 2014). b Unnamed specimen (based on Selden and Ren 2017). c Unnamed specimen (based on Xia et al. 2015). d Kronocharon engeli (based on Wunderlich 2015). e Kronocharon longicalcaris (based on Wunderlich 2015). f Unnamed specimen (based on Xia et al. 2015). g Unnamed specimen 11095 (based on Gröhn 2015)

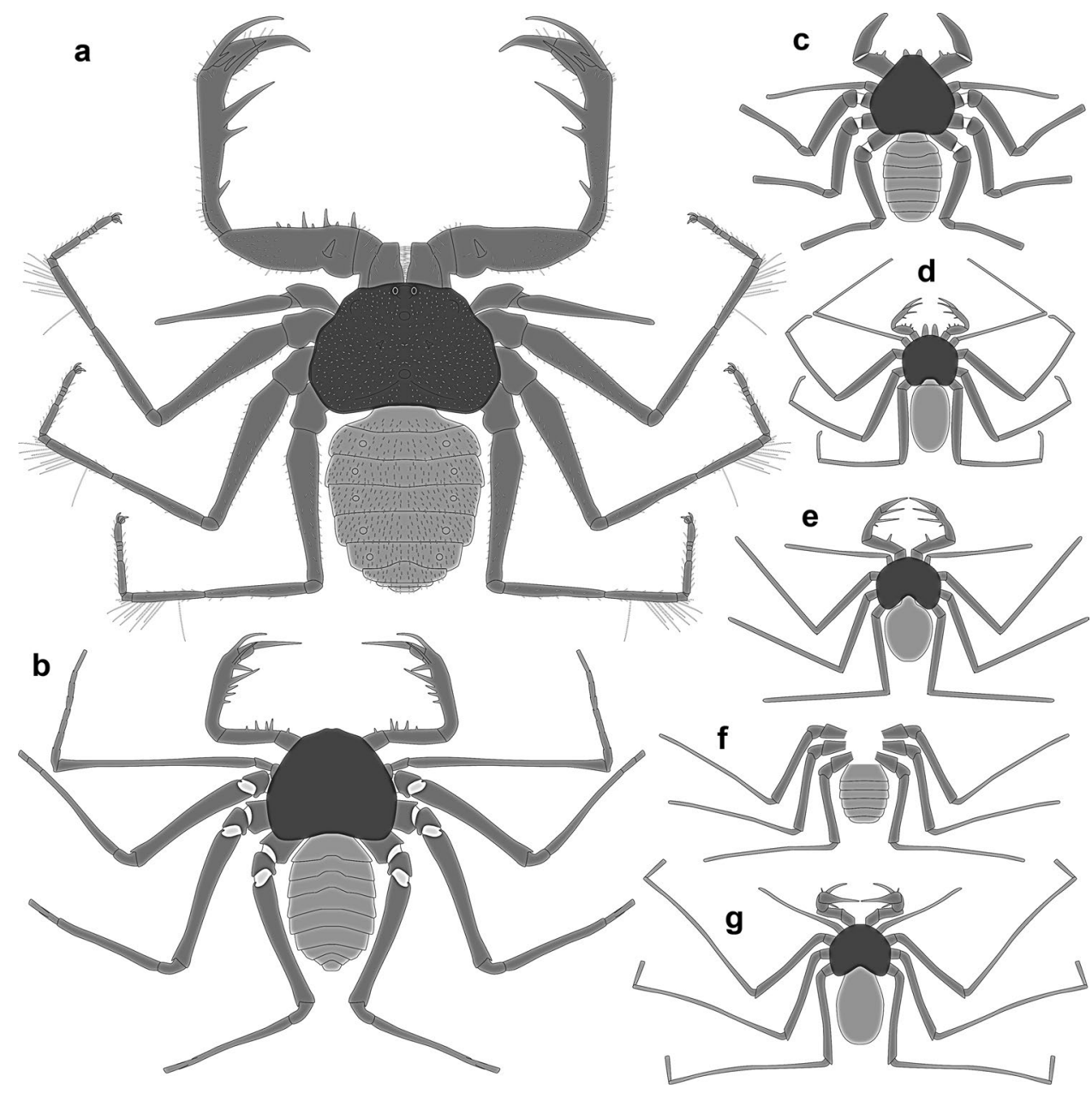

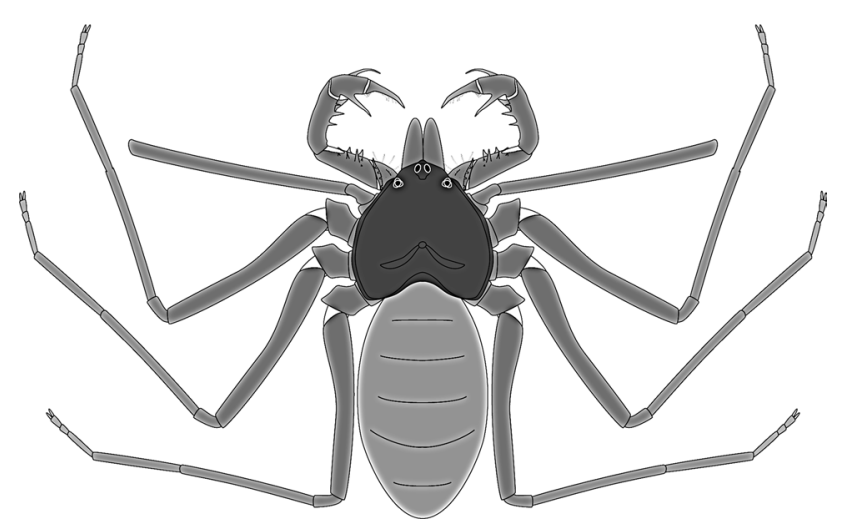

Fig. 15 Simplified representation of a whip spider from amber from Myanmar, Burmacharon dunlopi, NIGP173207 (based on Hu et al. 2020)

galla (2015) provided a better documentation of the specimen (Fig. 2), but concluded that the species is a nomen dubium, as the specimen is rather incomplete. It mostly provides some details of the pedipalp and few aspects of the proximal regions of the locomotory appendages.

(35) Specimen Do 1703-K-1 (Fig. 19b) is the holotype of Phrynus resinae (originally Tarantula resinae; Schawaller 1979). The specimen is preserved in Dominican Miocene amber. The specimen is accessible in dorsal view (Fig. 1) and ventral view (Fig. 2). Also many small details are accessible, including details of the pedipalp (Fig. 3) and of the locomotory appendages (Fig. 5).

(36) Specimen Do-3357 (Fig. 19c) is another specimen of Phrynus resinae (Schawaller 1982). It is also preserved in Dominican Miocene amber. The specimen is well accessible in dorsal view (Fig. 7); also some aspects of the inner skeleton are accessible (Fig. 8).

(37) Specimen Do-1370 (Fig. 19d) is another specimen of Phrynus resinae (Schawaller 1982). It is also preserved in Dominican Miocene amber. A habitus image of the specimen was not provided, only details of the feeler appendages (Fig. 2).

(38) Specimen Do-3000 (Fig. 20a) is another specimen of Phrynus resinae (Schawaller 1982). It is also pre- 


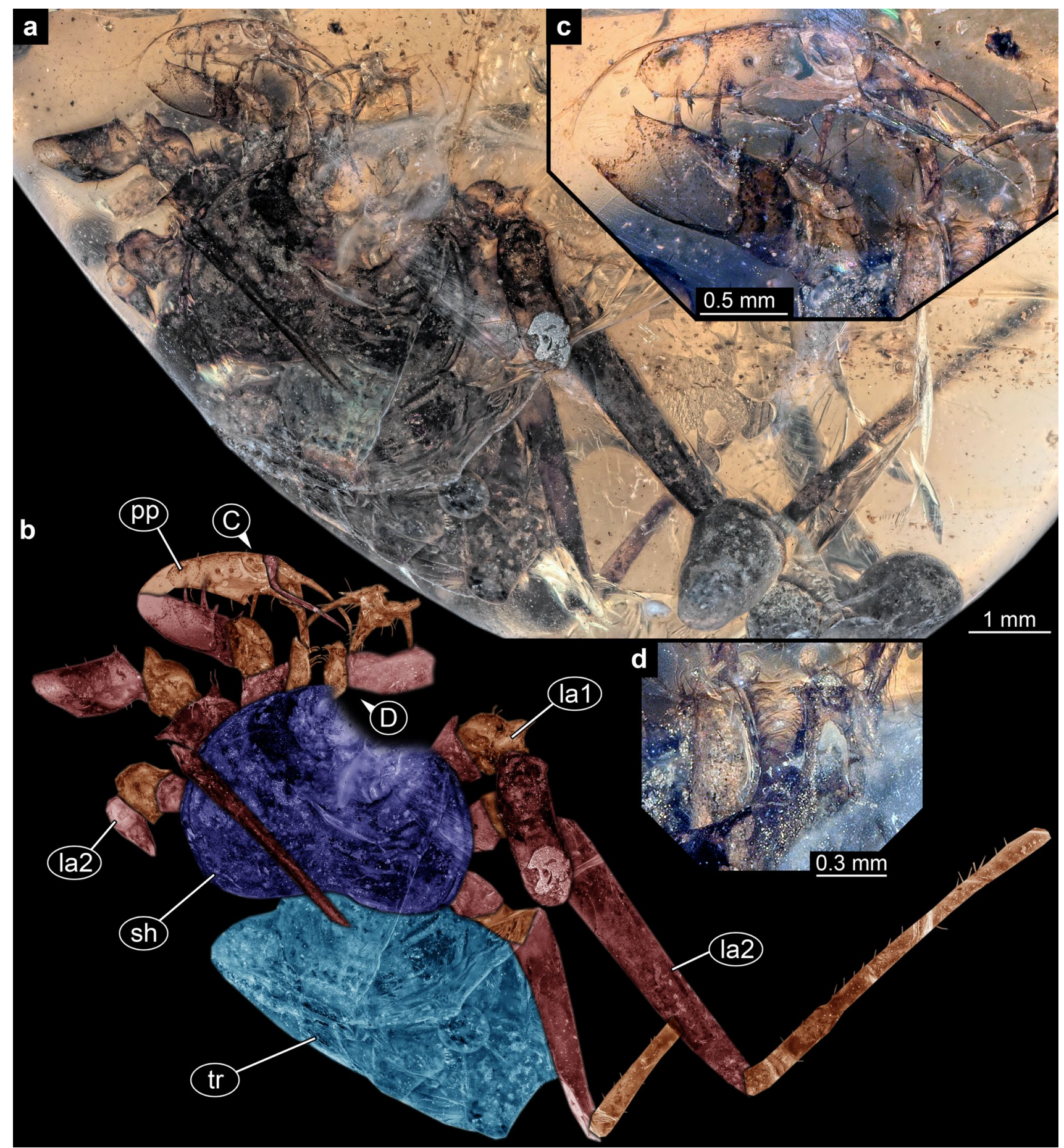

Fig. 16 New whip spider specimen from amber from Myanmar, PED 0099. a Overview dorsal view. b Colour-marked version of a. c Close-up on pedipalp. d Close-up on chelicerae

served in Dominican Miocene amber. The specimen is well accessible in dorsal view (Fig. 8); also details of the pedipalps are accessible (Fig. 4).

(39) A specimen (Fig. 20b) is an exuvium of the group Phrynus (Poinar 1992: 221, fig. 114). It is also pre- served in Dominican Miocene amber. The specimen is well accessible in dorsal view (221, fig. 114).

(40) Another specimen (Fig. 20c) is also a representative of Phrynus (Poinar and Poinar 1999: 78, between pp. 110/111, fig. 78), preserved in Dominican amber. The 


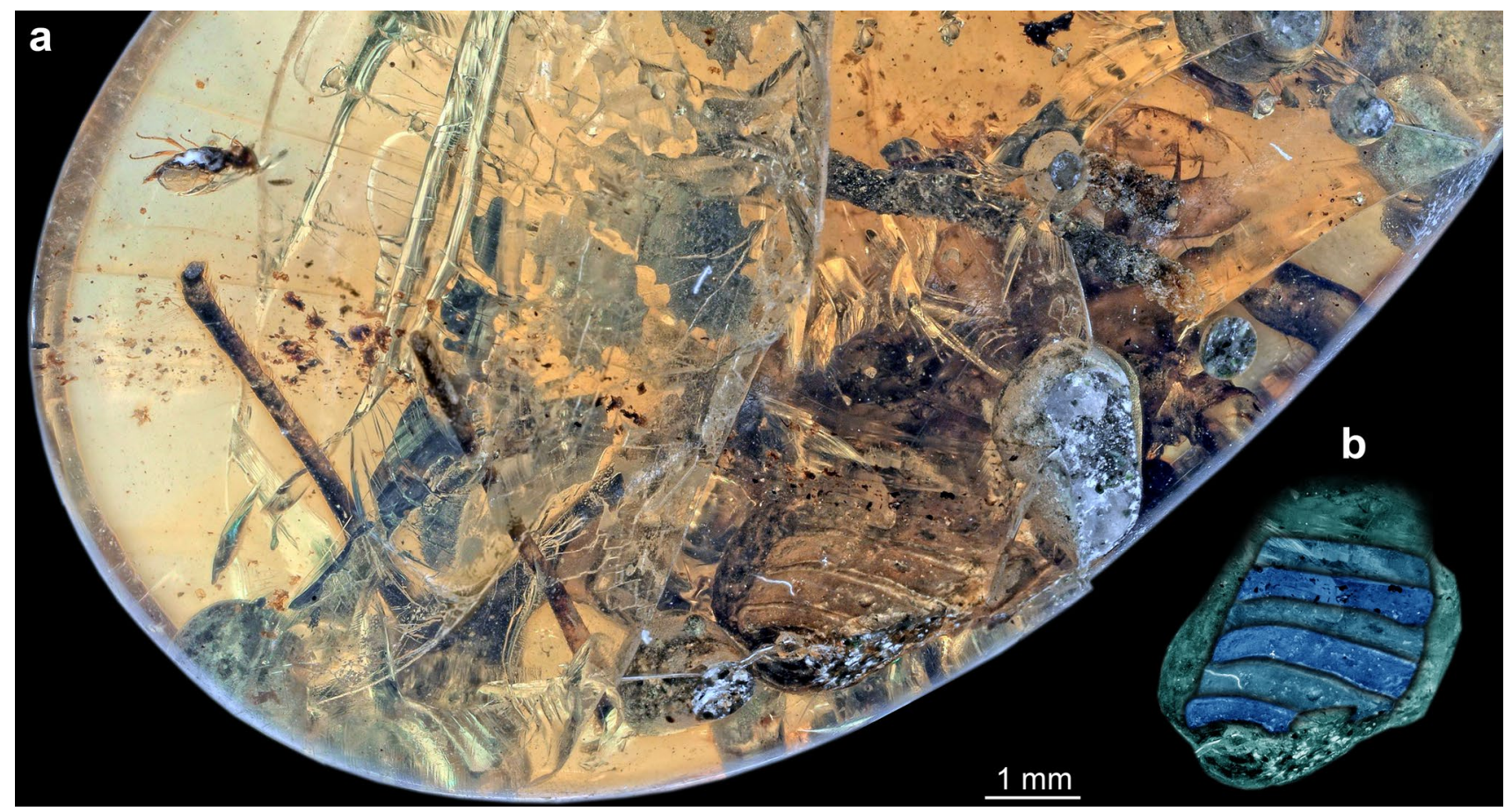

Fig. 17 New whip spider specimen from amber from Myanmar, PED 0099, continued. a Overview ventral view. b Colour-marked detail of a, trunk

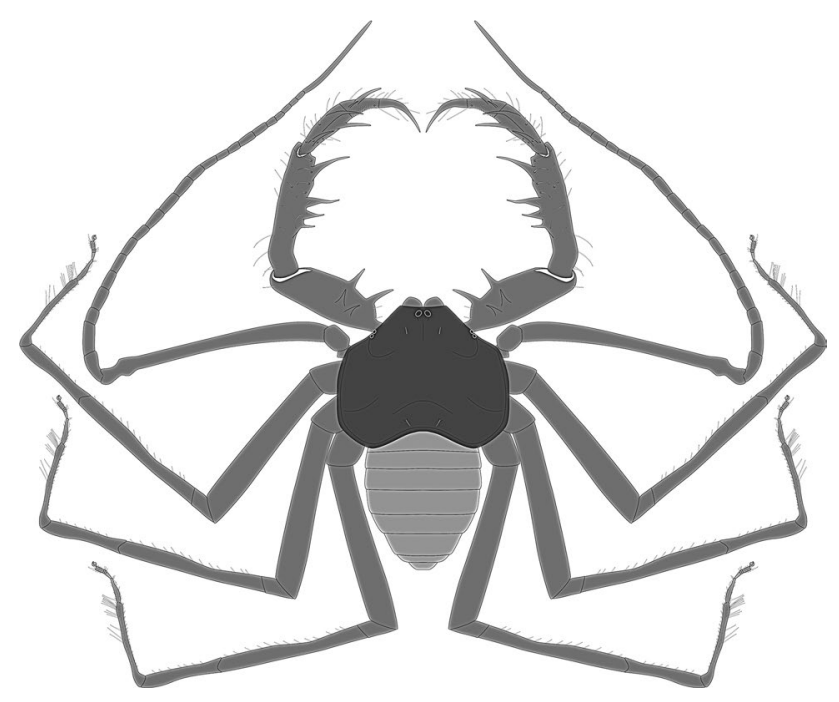

Fig. 18 Simplified representation of only known whip spider from Eocene amber, Paracharonopsis cambayensis, Tad 456 (based on Engel and Grimaldi 2014)

image provided is rather small and does not provide many details. We still try to provide here an interpretation of the principle morphology. Still, we feel uncertain in some aspects and do not consider the specimen for measurements here.
(41) A specimen (Fig. 20d) is beautifully preserved in Dominican Miocene amber (Wunderlich 2004: 594, photo 695). The specimen is incredibly complete, including the feeler-like appendages.

(42) A specimen is the holotype of Phrynus mexicanus (Fig. 20e; originally Phrynus mexicana, see discussion in Dunlop and Mrugalla 2015) described by Poinar and Brown (2004). The fossil is preserved in Miocene Chiapas amber (Mexico). An overview was provided as a photograph (594, photo 696), details were provided as drawings, including central body (Fig. 1), pedipalps (Figs. 2-7), eye region (Fig. 6), chelicerae (Fig. 7), and distal region of leg (Fig. 8).

In total, there are so far 37 fossil whip spiders to be considered here as specimens mentioned under 1, 2, 20, 22, and 40 are not included (see specimen descriptions above). However, four of these specimens did not show sufficient preservation to measure all relevant structures, hence could not be considered further. Therefore, 15 specimens from the Carboniferous, eleven from the Cretaceous, one from the Eocene, and six from the Miocene were included into the analysis (Table 1).

Plotting the length-width ratios of trunk vs shield reveals a distinct pattern (Fig. 21). Carboniferous specimens plot further to the upper right. Modern specimens 
Fig. 19 Simplified representations of whip spiders from Miocene ambers. a Mexican amber, Electrophrynus mirus, UCMP B-7043-22, sp-no. 13545 (based on Dunlop and Mrugalla 2015). b-d Dominican amber, Phrynus resinae. b Do 1703-K-1 (based on Schawaller 1979). c Do-3357 (based on Schawaller 1982). d Do-1370 (based on Schawaller 1982)

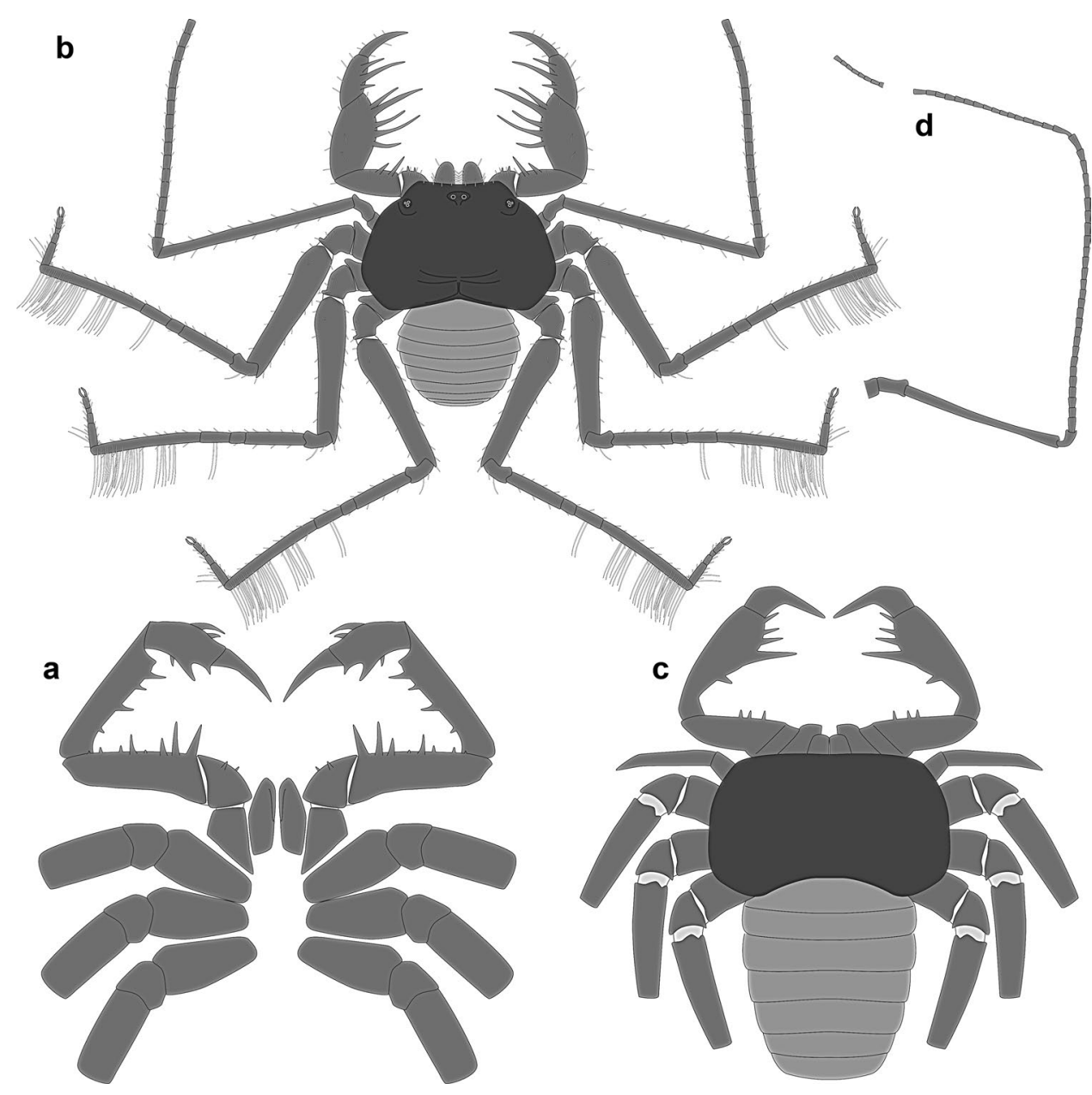

occupy a larger range, but plot more to the lower left with one exception, namely Paracharon caecus, which plots in the upper right area. Specimens from the Cretaceous and Eocene/Miocene plot in between. There is a large overlap of the groups, not a distinct separation.

Plotting also other ratios reveals a similar pattern (Fig. 22). For the ratios of the pedipalp (pedipalp/shield, pedipalp/trunk), the weight point of the group of Carboniferous specimens forms one extreme, the weight point of the group of modern specimens the other one. The weight points of the groups of Cretaceous specimens and Eocene/ Miocene specimens are intermediate.

For the ratio length(leg)/length(shield), the weight point for the group Eocene/Miocene is more extreme than the weight point of the group of Carboniferous specimens. For the ratio of length(leg)/length(trunk), the weight point of the group of Cretaceous specimens is slightly more extreme than that of the group of modern specimens.

\section{Discussion}

\section{Challenges of general terminology of Amblypygi}

As a general observation within Euarthropoda, comparisons in a wider frame are often challenging due to highly specific ingroup terminology. This is a direct consequence of the different traditions of many sub-fields of research on the group Euarthropoda. Yet, at a certain point, mostly when "walking down the tree", complications become more easily apparent. This is also the case in Amblypygi. It should be well known that terms such as dorsal or ventral can be applied to positions of structures of the main axis, i.e. on the central body, but become meaningless for structures on the appendages, as they can be moved against the main axis (see e.g. discussion in Hörnig et al. 2013). Still, it is a tradition to address the spines on the (mostly horizontally held) pedipalps of Amblypygi as dorsal and 
Fig. 20 Simplified representations of whip spiders from Miocene ambers. a-d Dominican amber. a Phrynus resinae, Do-3000 (based on Schawaller 1982). b Specimen of Phrynus (based on Poinar 1992). c Specimen of Phrynus (based on Poinar and Poinar 1999). d Specimen based on Wunderlich (2004). e Mexican amber, Phrynus mexicanus (based on Poinar and Brown 2004)

Fig. 21 Scatter plot of lengthwidth ratio of trunk vs lengthwidth ratio of shield of whip spiders; specimens from similar time slices depicted with same symbols
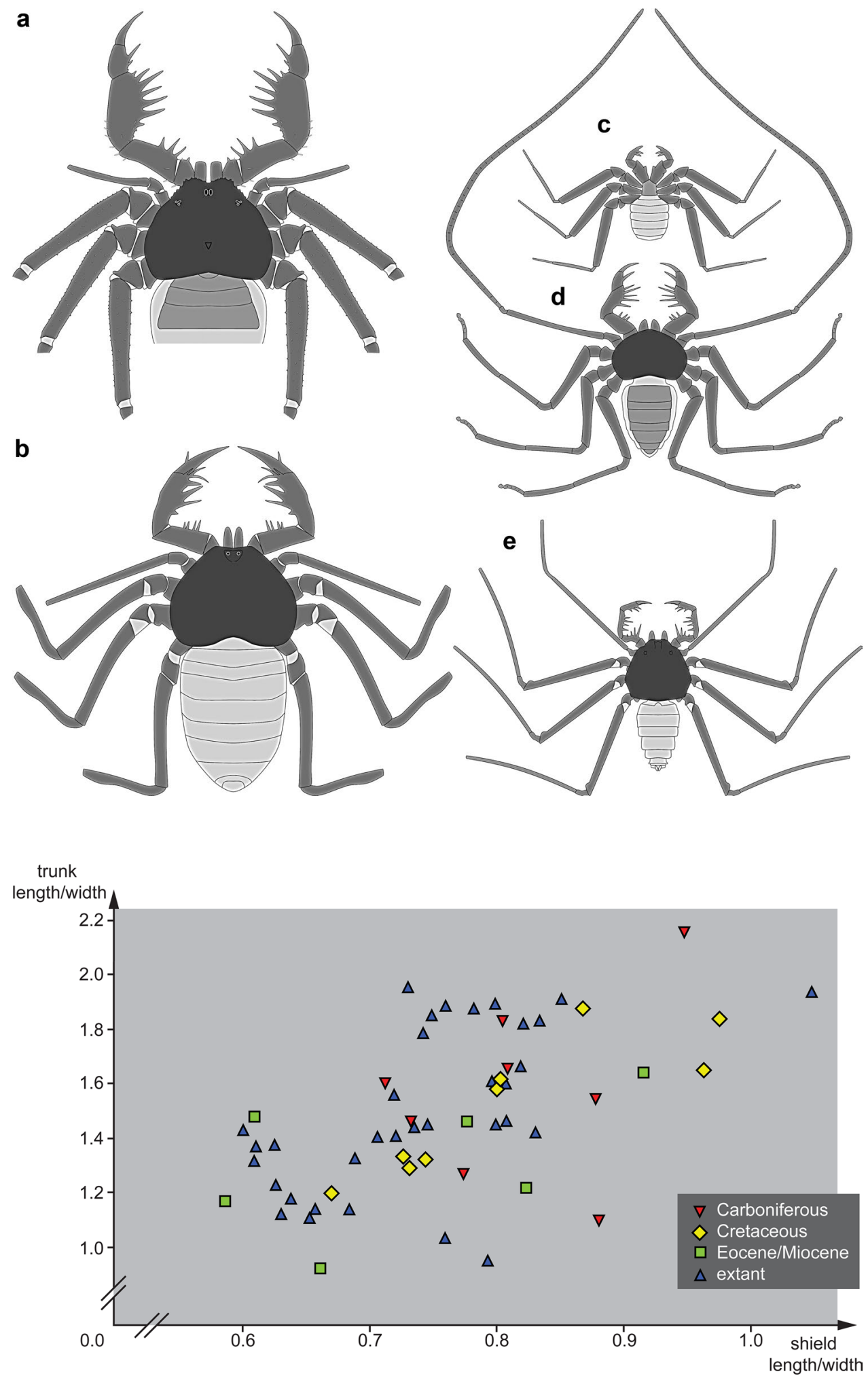

ventral spines. Yet, for the extant species Paracharon caecus, these terms appear inappropriate due to the nearly vertical orientation of the pedipalps (Garwood et al. 2017: fig. 2). The terms can be well correlated when comparing the pedipalps to those of other modern forms. Yet, this would mean to provide an upward frame of comparison, i.e. interpret a possibly more plesiomorphic morphology (as seen in P. caecus) in the light of a possibly more derived one (as in representatives of Euamblypygi, the group including all extant species of Amblypygi besides 
Fig. 22 Range of different ratios for whip spiders from different time slices. $C$ Carboniferous, $E c$ Eocene, $e x$ extant, $K$ Cretaceous, $M c$ Miocene

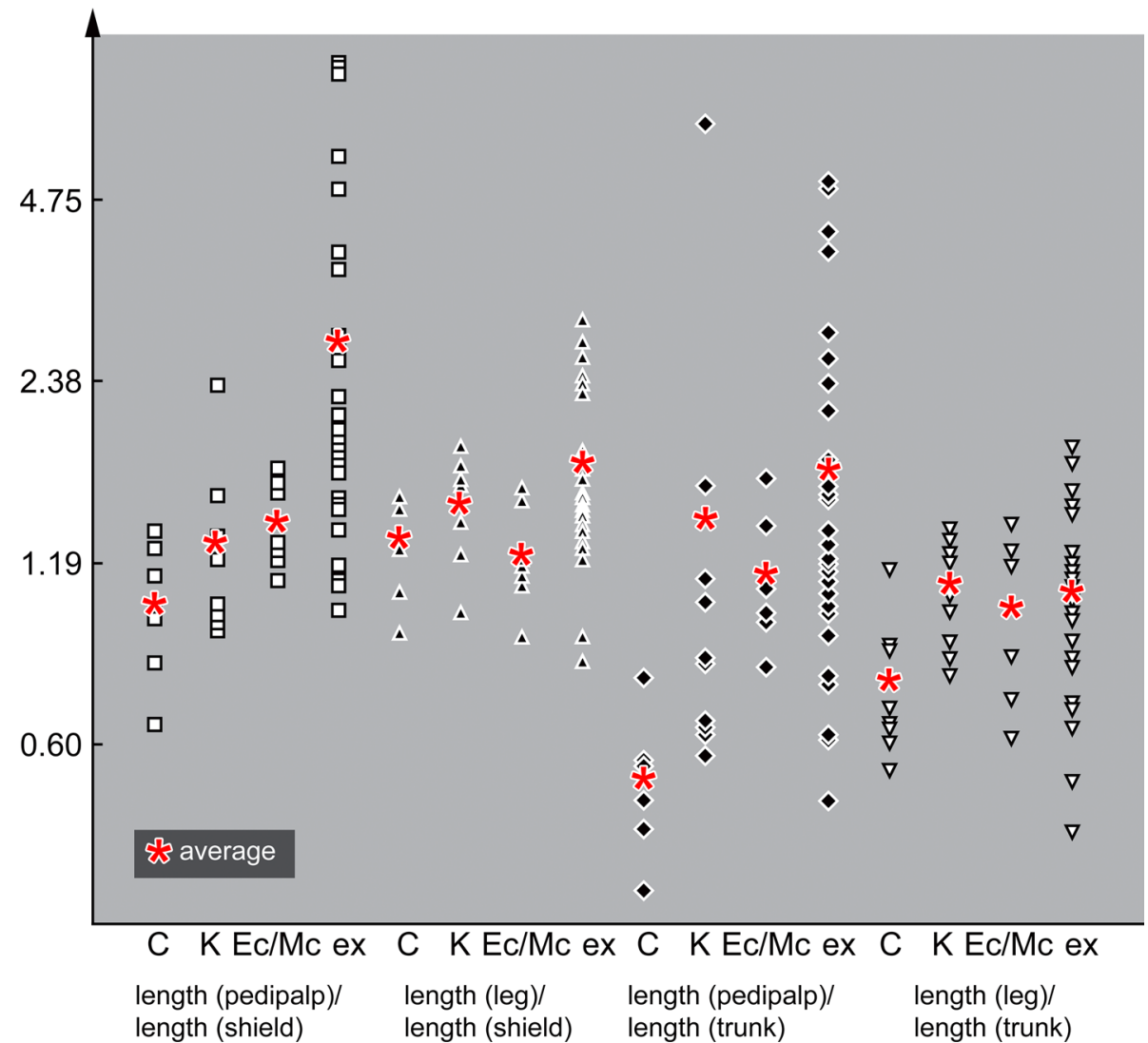

possibly one species, see "Discussion" below and Garwood et al. 2017: fig. 6).

Especially for future wider-scaled comparisons (e.g. with Thelyphonida and Schizomida), it seems much more feasible to use a more neutral terminology. We, therefore, use the frame for describing appendages as outlined in Hörnig et al. (2013), i.e. the appendages are imagined in a hanging position, with the spines being situated on the median side and the opposite side being the lateral side (this is the ancestral orientation for Euarthropoda); this results in a clear anterior and posterior side of the appendage. In this way, not only the morphology of $P$. caecus can be addressed without an assumptive frame, but especially also the morphology of some of the fossil species can be referred to in a more neutral manner.

\section{Morphological interpretation of Weygoldtina anglica}

The CT-based study by Garwood et al. (2017) already indicated that the pedipalps of the Carboniferous whip spider Weygoldtina anglica seem not to move in a horizontal plane. Hence, this is unlike in modern day representatives of Euamblypygi, but more similar to the modern species Paracharon caecus.

Yet, the case is apparently more complicated. For example, also representatives of Euamblypygi can move their pedipalps in a way that the plane of action is at about $45^{\circ}$ right between the horizontal and the vertical plane (Carvalho et al. 2011: fig. 1).

Indeed $W$. anglica appears to have moved its pedipalps strongly in the vertical plane. Yet there seems to be also a certain degree of movability of this plane of action, most likely due to the orientation of the proximal joints of the pedipalps. In one specimen (Fig. 7; see also Garwood et al. 2017: fig. 3B), the planes of action of the two pedipalps seem to form an angle of $90^{\circ}$ against each other. This is more or less comparable to the upper-most position of modern representatives of Euamblypygi (Carvalho et al. 2011: fig. 1). For $W$. anglica this appears to be more or less equivalent to the lower-most position. This is indicated by other specimens in which the angle between the planes of action of the two pedipalps is smaller (e.g. Figs. 5, 9), and in some they appear more or less parallel, i.e. indeed vertical (Figs. 3, $8,10)$. For differentiating such details, the documentation with a method providing 3D information (CT scanning in Garwood et al. 2017, but also stereo-imaging as in this study) is important.

The spine orientation of the pedipalps of Weygoldtina anglica seems to differ from that in pedipalps of the modern species of Paracharon caecus. The spines in P. caecus appear to be almost parallel, slightly tilted outwards. In the pedipalps of $W$. anglica, the angle between the spines 
appears to be larger, at least $90^{\circ}$, i.e. the spines appear further oriented outwards. This indicates that $W$. anglica used its pedipalps not exactly in the same way as the modern $P$. caecus. The arrangement is more comparable to that seen in the pedipalps of the armoured harvestman Iandumoema uai (do Monte et al. 2015: fig. 3A). Yet, this is still not entirely comparable. In the whip spider $P$. caecus, and also in the armoured harvestman $I$. uai, the left and right pedipalp appear to be well functionally separated, i.e. appear to be able to act on their own. For the pedipalps of Weygoldtina anglica this seems to be different. The anterior spines are long and extend far outward, i.e. functionally medially. The spines are so long that they overlap, and hence both pedipalps may form a single, vertically closing basket. In some modern representatives of Amblypygi with rather short pedipalps the spines also interfere and can form a single functional basket (Carvalho et al. 2011: fig. 1). Yet, as the plane of action is different, this will again not be fully comparable.

Assuming a downward movement of the feeding basket, this would bring a possible prey item close to the basipods (coxae) of the pedipalps and the adjacent basipods of the locomotory appendage 1 . It therefore seems well possible that the newly observed, massive-appearing spines are also involved in the feeding process. Among modern species there seem to be no such spines. Also, in modern species the basipods of locomotory appendages are further posterior and less forward oriented compared than those in W. anglica. This correlates with the rather small and less prominent basipods of the pedipalps in W. anglica. This is a further difference to the modern species $P$. caecus. Here, the basipods of pedipalps and locomotory appendages resemble the condition in representatives of Euamblypygi.

\section{Phylogenetic interpretation of fossil whip spiders}

The phylogenetic analysis of Garwood et al. (2017) represented an important step for our understanding of the evolution of Amblypygi. Based on some of the details observed here, we want to point out some aspects that should be considered in a future expanded phylogenetic analysis.

Palaeoamblypygi has been resolved as a monophyletic group including the extant species Paracharon caecus, Paracharonopsis cambayensis from Eocene amber, and Weygoldtina (originally Graephonus) represented by Carboniferous fossils. The group is characterised by the anterior protrusion of the shield. While Garwood et al. (2017) considered the possibility that Palaeoamblypygi is not monophyletic, they considered the projection as a true apomorphy. The argument is, yet, not as strong as suggested. The shield of whip scorpions (Thelyphonida) could well also be understood as drawn out anteriorly. Also the feature appears not as unique as suggested, as also some modern species of
Euamblypygi show this type of morphology (e.g. Teruel and Questel 2015: fig. 2a).

Under this aspect, the differences in morphology of the basipods of pedipalps and locomotory appendage 1 in Paracharon caecus and Weygoldtina could provide a signal for a closer relationship of Paracharon caecus and Euamblypygi. Yet, this could also well point to an apomorphic condition of Weygoldtina or W. anglica. In general, it needs to be considered that Weygoldtina is not as similar to Paracharon caecus as a brief look might suggest, but is characterised by own specialisations.

Also the interpretation by Garwood et al. (2017) of the species Paracharonopsis cambayensis from Eocene amber as closely related to Paracharon caecus should be considered with care. The schematic drawing of the pedipalps (Garwood et al. 2017: fig. 6) indicates a strong morphological similarity. Yet, a closer comparison of the morphology (Engel and Grimaldi 2014; see also Fig. 6) clearly reveals that this pedipalp is much more of the normal, Euamblypygitype morphology. Especially there is clear indication that it is strongly foldable and acting mostly in the horizontal plane. These characters clearly indicate a closer relationship, or even an ingroup position within Euamblypygi for $P$. cambayensis, especially as also modern representatives of Euamblypygi have a protruding shield (e.g. Teruel and Questel 2015: fig. 2a).

\section{Changes in whip spider morphology through time}

While there might remain some uncertainties of the phylogenetic history of Amblypygi, as discussed above, we can still consider some changes through time. Plotting the measured values of all observed fossils and a representative fraction of modern forms reveals some recognisable changes through time.

Only a weak shift is observable concerning overall shape of the shield and the trunk (Fig. 21). Yet, it is well apparent that in the Carboniferous, the shields were, at least on average, more elongate. This appears to account also for the trunk. In the Cretaceous, there is a slight shift towards broader forms, further continued into even broader forms in the modern fauna, with the exception of Paracharon caecus with a relatively elongate shield. The Eocene/Miocene fauna is most likely partly biased (see below), representing quite broad forms.

The ratios of appendage lengths vs length of shield or trunk show a clearer signal (Fig. 22), most likely due to the stronger variability in width, especially in the case of the trunk. It is well apparent that the relative length of pedipalp and locomotory appendages was rather short in the Carboniferous, increased in the Cretaceous, and became highly variable, but on average longer in the modern fauna. Again the Eocene/Miocene does not follow the overall trend, yet this is 
likely due to the fact that the available sample size is rather low and possibly only represents few species, and especially in the Miocene all from the group Phrynus.

Independent of the exact phylogenetic relationships, we see a clear shift in the morphology of whip spiders over time. More extreme-appearing forms with strongly elongated appendages started to occur in the Mesozoic, but seem only to have diversified after the Cretaceous-Palaeogene transition.

\section{Future directions}

It is to be expected that especially ambers will in the near future provide many more specimens of Amblypygi. Amber from Myanmar definitely has produced several more specimens that occurred on the open market. The present study represents a current state of available fossil representatives of Amblypygi and by this a kind of to-be-expanded database.

Acknowledgments Our thanks go to Jason Dunlop, Berlin, Mike Reich, Munich, and an anonymous reviewer for helpful comments on the manuscript. We thank Markus Sennlaub, Hanau, and Claire Mellish, London, for providing access to the specimens. We are grateful to J. Matthias Starck, Munich, for discussions and general support. We thank all people providing free software. $\mathrm{CH}$ is grateful for funding via a Bavarian Equal Opportunities Sponsorship (BGF) of the LMU Munich. This study is part of a project of $\mathrm{CH}$ funded by the German Research Foundation (DFG) under HA 7066/3-1. It was kindly supported by the Volkswagen Foundation with a Lichtenberg Professorship to JTH. The research visit to the NHM London was made possible by a grant from the European Commission's (FP 6) Integrated Infrastructure Initiative program SYNTHESYS (GB-TAF-4057) to $\mathrm{CH}$.

Funding Open Access funding enabled and organized by Projekt DEAL.

Open Access This article is licensed under a Creative Commons Attribution 4.0 International License, which permits use, sharing, adaptation, distribution and reproduction in any medium or format, as long as you give appropriate credit to the original author(s) and the source, provide a link to the Creative Commons licence, and indicate if changes were made. The images or other third party material in this article are included in the article's Creative Commons licence, unless indicated otherwise in a credit line to the material. If material is not included in the article's Creative Commons licence and your intended use is not permitted by statutory regulation or exceeds the permitted use, you will need to obtain permission directly from the copyright holder. To view a copy of this licence, visit http://creativecommons.org/licenses/by/4.0/.

\section{References}

Armas, L.F. de, and A.A.A. Arias. 2008. Nueva especie de Phrynus Lamarck, 1801 (Amblypygi: Phrynidae) de Colombia. Boletin Sociedad Entomológica Aragonesa 43: 25-28.

Armas, L.F. de. 2014. Los amblipigios de Cuba (Arachnida: Amblypygi). Revista Ibérica de Aracnología 24: 29-51.
Carvalho, L.S., F.N. Oliveira-Marques, and P.R.R. Silva. 2011. Arachnida, Amblypygi, Heterophrynus longicornis (Butler, 1873): distribution extension for the state of Piauí northeastern Brazil. Check List 7: 267-269.

Chapin, K.J., and E.A. Hebets. 2016. The behavioral ecology of amblypygids. Journal of Arachnology 44: 1-14.

Chapin, K.J., and S. Reed-Guy. 2017. Territoriality mediates atypical size-symmetric cannibalism in the Amblypygi Phrynus longipes. Ethology 123(10): 772-777.

Cokendolpher, J.C., and W.D. Sissom. 2001. A new troglobitic Paraphrynus from Oaxaca, Mexico (Amblypygi, Phrynidae). Texas Memorial Museum, Speleological Monographs 5: 17-23.

Dunlop, J.A. 1994. An Upper Carboniferous amblypygid from the Writhlington Geological Nature Reserve. Proceedings of the Geologists' Association 105(4): 245-250.

Dunlop, J.A. 2018. Systematics of the Coal Measures whip spiders (Arachnida: Amblypygi). Zoologischer Anzeiger 273: 14-22.

Dunlop, J.A., and V. Barov. 2005. A new fossil whip spider (Arachnida: Amblypygi) from the Crato Formation of Brazil. Revista Ibérica de Aracnología 12: 53-62.

Dunlop, J.A., and D.M. Martill. 2001. The first whipspider (Arachnida: Amblypygi) and three new whipscorpions (Arachnida: Thelyphonida) from the Lower Cretaceous Crato Formation of Brazil. Earth and Environmental Science Transactions of the Royal Society of Edinburgh 92(3): 325-334.

Dunlop, J.A., and B. Mrugalla. 2015. Redescription of the Chiapas amber whip spider Electrophrynus mirus (Amblypygi). The Journal of Arachnology 43(2): 220-224.

Dunlop, J.A., G.R. Zhou, and S.J. Braddy. 2007a. The affinities of the Carboniferous whip spider Graeophonus anglicus Pocock, 1911 (Arachnida: Amblypygi). Earth and Environmental Science Transactions of the Royal Society of Edinburgh 98(2): 165-178.

Dunlop, J.A., F. Menon, and P.A. Selden. 2007b. Arachnida: spiders, scorpions and allies. In The Crato fossil beds of Brazil: window into an ancient world, eds. D.M. Martill, G. Bechly, and R.F. Loveridge, 103-132. Cambridge: Cambridge University Press.

El-Hennawy, H.K. 2002. The first record of Amblypygi from Egypt. The Journal of Arachnology 30: 452-453.

Engel, M.S., and D.A. Grimaldi. 2014. Whipspiders (Arachnida: Amblypygi) in amber from the Early Eocene and mid-Cretaceous, including maternal care. Novitates Paleoentomologicae 9: 1-17.

García Rivera, L., R. Montes Espín, L.F. de Armas, and N. Hernández Hernández. 2009. Necrofagia en Amblypygi (Arachnida: Pedipalpi). Boletín Sociedad Entomológica Aragonesa 45: 505-507.

Garwood, R.J., J.A. Dunlop, B.J. Knecht, and T.A. Hegna. 2017. The phylogeny of fossil whip spiders. BMC Evolutionary Biology 17(1): art. 105.

Giupponi, A.P.L., and R.C.L. Baptista. 2003. Primeiro registro fóssil de Phrynichidae (Amblypygi). In IV Encontro de Aracnólogos do Cone Sul, São Pedro, 7-12 Dezembro 2003, Programa and Resumos, eds. G. Machado, and A.D. Brescovit, 104.

Giupponi, A.P., and G.S. Miranda. 2012. A new species of Sarax Simon, 1892 from the Philippines (Arachnida: Amblypygi: Charinidae). Anais da Academia Brasileira de Ciências 84(1): 165-174.

Gröhn, C. 2015. Einschlüsse im baltischen Bernstein, 1-424. Kiel: Wachholtz Verlag/Murmann Publishers.

Harvey, M.S. 2003. Catalogue of the smaller arachnid orders of the world: Amblypygi, Uropygi, Schizomida, Palpigradi, Ricinulei and Solifugae, 1-385. Collingwood: CSIRO publishing.

Haug, J.T., C. Haug, and M. Ehrlich. 2008. First fossil stomatopod larva (Arthropoda: Crustacea) and a new way of documenting Solnhofen fossils (Upper Jurassic, Southern Germany). Palaeodiversity 1: 103-109.

Haug, C., P. Van Roy, A. Leipner, P. Funch, D.M. Rudkin, L. Schöllmann, and J.T. Haug. 2012. A holomorph approach 
to xiphosuran evolution-a case study on the ontogeny of Euproops. Development Genes and Evolution 222: 253-268.

Haug, C., K.R. Shannon, T. Nyborg, and F.J. Vega. 2013. Isolated mantis shrimp dactyli from the Pliocene of North Carolina and their bearing on the history of Stomatopoda. Bolétin de la Sociedad Geológica Mexicana 65: 273-284.

Haug, J.T., C.C. Labandeira, J.A. Santiago-Blay, C. Haug, and S. Brown. 2015. Life habits, hox genes, and affinities of a 311 million-year-old holometabolan larva. BMC Evolutionary Biology 15: art. 208.

Hörnig, M.K., J.T. Haug, and C. Haug. 2013. New details of Santanmantis axelrodi and the evolution of the mantodean morphotype. Palaeodiversity 6: 157-168.

Hu, X., X. Lei, C. Luo, E.A. Jarzembowski, B. Wang, and C. Xiao. 2020. A new whip spider (Arachnida: Amblypygi) in midCretaceous Kachin amber. Cretaceous Research 116: 104596.

Kerp, H., and B. Bomfleur. 2011. Photography of plant fossils-new techniques, old tricks. Review of Palaeobotany and Palynology 166: 117-151.

Kury, A.B., A. Chagas-Jr, A.P. Giupponi, and A.P. González. 2010. Amblypygi, Opiliones, Schizomida, Scorpiones and Chilopoda, Tocantins, Brazil. Check List 6(4): 564-571.

Maquart, P.O., F. Révellion, L. Prendini, M. Burger, B.L. Fisher, and S. van Noort. 2016. New distribution records for African whip spiders (Arachnida: Amblypygi). African Entomology 24: 245-246.

Miranda, G.S., M. Milleri-Pinto, T. Gonçalves-Souza, A.P. de Leão Giupponi, and N. Scharff. 2016. A new species of Charinus Simon 1892 from Brazil, with notes on behavior (Amblypygi, Charinidae). ZooKeys 621: 15-36.

Miranda, G.S. de, A.P. Giupponi, L. Prendini, and N. Scharff. 2018a. Weygoldtia, a new genus of Charinidae Quintero, 1986 (Arachnida, Amblypygi) with a reappraisal of the genera in the family. Zoologischer Anzeiger 273: 23-32.

Miranda, G.S. de, A.B. Kury, and A.P. de Leão Giupponi. 2018b. Review of Trichodamon Mello-Leitão 1935 and phylogenetic placement of the genus in Phrynichidae (Arachnida, Amblypygi). Zoologischer Anzeiger 273: 33-55.

Monte, B.G.O. do, J.E. Gallão, D.M. von Schimonsky, and M.E. Bichuette. 2015. New records of two endemic troglobitic and threatened arachnids (Amblypygi and Opiliones) from limestone caves of Minas Gerais state, southeast Brazil. Biodiversity Data Journal 3: e5260.

Petrunkevitch, A.I. 1913. A monograph of the terrestrial Palaeozoic Arachnida of North America. Transactions of the Connecticut Academy of Arts and Sciences 18: 1-137.

Petrunkevitch, A.I. 1949. A study of Palaeozoic Arachnida. Transactions of the Connecticut Academy of Arts and Sciences 37: 69-315.

Petrunkevitch, A.I. 1953. Paleozoic and Mesozoic Arachnida of Europe. Memoirs of the Geological Society of America 53: $1-128$.

Petrunkevitch, A.I. 1971. Chiapas amber spiders, II. University of California Publications in Entomology 63: 1-44.

Pocock, R.I. 1911. A monograph of the terrestrial Carboniferous Arachnida of Great Britain. Monograph of the Palaeontographical Society 1911: 1-84.

Poinar, G.O., Jr. 1992. Life in amber, 1-368. Stanford: Stanford University Press.

Poinar, G., Jr., and A.E. Brown. 2004. A new whip spider (Arachnida: Amblypygi), Phrynus mexicana, is described from Mexican amber. In Beiträge zur Araneologie 3. Fossil Spiders in Amber and Copal: Fossile Spinnen in Bernstein und Kopal, ed. J. Wunderlich, 1881-1885. Hirschberg: Publishing House J. Wunderlich.
Poinar, G.O., Jr., and R. Poinar. 1999. The amber forest: a reconstruction of a vanished world. Princeton: Princeton University Press.

Prendini, L., P. Weygoldt, and W.C. Wheeler. 2005. Systematics of the Damon variegatus group of African whip spiders (Chelicerata: Amblypygi): evidence from behaviour, morphology and DNA. Organisms Diversity and Evolution 5(3): 203-236.

Prous, X., T. Pietrobon, M.S. Ribeiro, and R.D.A. Zampaulo. 2017. Bat necrophagy by a whip-spider (Arachnida, Amblypygi, Phrynidae) in a cave in the eastern Brazilian Amazon. Acta Amazonica 47(4): 365-368.

Rahmadi, C., and M.S. Harvey. 2008. A first epigean species of Stygophrynus Kraepelin (Amblypygi: Charontidae) from Java and adjacent islands, Indonesia with notes on $S$. dammermani Roewer, 1928. Raffles Bulletin of Zoology 56(2): 281-288.

Réveillion, F., and P.O. Maquart. 2015. A new species of Charinus Simon, 1892 (Amblypygi, Charinidae) from termite nests in French Guiana. Zootaxa 4032(2): 190-196.

Réveillion, F., and P.O. Maquart. 2018. A new species of Charon (Amblypygi: Charontidae) from Orchid Island (Taiwan). Revista Ibérica de Aracnologìa 32: 31-36.

Santos Silva, J.A. dos. 2017. Um novo gênero e espécie de Amblipígeo (Arachnida: Amblypygi: Charinidae) do Membro Crato (Aptiano), Formação Santana, Bacia do Araripe. Master thesis. Fortaleza: Universidade Federal do Ceará.

Schawaller, W. 1979. Erstnachweis der Ordnung Geißelspinnen in Dominikanischem Bernstein (Stuttgarter Bernsteinsammlung: Arachnida, Amblypygi). Stuttgarter Beiträge zur Naturkunde. Serie B (Geologie und Paläontologie) 50: 1-12.

Schawaller, W. 1982. Neue Befunde an Geißelspinnen in Dominikanischem Bernstein:(Stuttgarter Bernsteinsammlung: Arachnida, Amblypygi). Stuttgarter Beiträge zur Naturkunde (B: Geologie und Paläontologie) 86: 1-12.

Scudder, S.H. 1876. New and interesting insects from the Carboniferous of Cape Breton. The Canadian Naturalist and Quarterly Journal of Science 8: 88-90.

Scudder, S.H. 1890. Illustrations of the Carboniferous Arachnida of North America, of the orders Anthracomarti and Pedipalpi. Memoirs read before the Boston Society of Natural History 4: 443-456.

Seiter, M., and C. Hörweg. 2013. The whip spider collection (Arachnida, Amblypygi) held in the Natural History Museum Vienna, Austria. Arachnologische Mitteilungen 46: 47-53.

Selden, P.A., and D. Ren. 2017. A review of Burmese amber arachnids. The Journal of Arachnology 45(3): 324-344.

Selden, P.A., W.A. Shear, and P.M. Bonamo. 1991. A spider and other arachnids from the Devonian of New York, and reinterpretations of Devonian Araneae. Palaeontology 34: 241-281.

Teruel, R., and L.F. de Armas. 2005. Novedades aracnológicas de República Dominicana (Arachnida: Amblypygi, Schizomida, Solpugida, Uropygi). Boletín de la Sociedad Entomológica Aragonesa 37: 129-133.

Teruel, R., and K. Questel. 2011. A new species of Charinus Simon 1892 (Amblypygi: Charinidae) from the Leeward Islands, Lesser Antilles. Boletín de la Sociedad Entomológica Aragonesa 49: 15-18.

Teruel, R., and K. Questel. 2015. A new species of Charinus Simon, 1892 (Amblypygi: Charinidae) from Guadeloupe, Lesser Antilles. Revista Ibérica de Aracnología 26: 43-47.

Torres, R.A., L.F. de Armas, and J. Tovar-Márquez. 2019. Aspects of the natural history of Phrynus barbadensis (Pocock, 1893) (Amblypygi: Phrynidae). Revista de la Sociedad Entomológica Argentina 78(1): 12-21.

Torres-Contreras, R., L.F. de Armas, and D.M. Ãlvarez-García. 2015. Cannibalism in whip spiders (Arachnida: Amblypygi). Revista Ibérica de Aracnología 26: 79-80. 
Víquez, C., D. Chirivi, J.A. Moreno-González, and J.A. Christensen. 2014. Heterophrynus armiger Pocock, 1902 (Amblypygi: Phrynidae): First record from Colombia, with notes on its historic distribution records and natural history. Check List 10(2): 457-460.

Weygoldt, P. 1969. Beobachtungen zur Fortpflanzungsbiologie und zum Verhalten der Geißelspinne Tarantula marginemaculata CL Koch (Chelicerata, Amblypygi). Zeitschrift für Morphologie der Tiere 64(4): 338-360.

Weygoldt, P. 1970. Lebenszyklus und postembryonale Entwicklung der Geißelspinne Tarantula marginemaculata CL Koch (Chelicerata, Amblypygi) im Laboratorium. Zeitschrift für Morphologie der Tiere 67(1): 58-85.

Weygoldt, P. 1977. Beobachtungen zum postembryonalen Wachstum von Trichodamon froesi Mello Leitao (Amblypygi, Arachnida). Zoomorphologie 86(3): 287-296.
Weygoldt, P. 2000. Whip spiders (Chelicerata: Amblypygi): their biology, morphology and systematics, 1-163. Stenstrup: Apollo Books.

Wunderlich, J. 2004. Beiträge zur Araneologie 3. Fossil Spiders in Amber and Copal: Fossile Spinnen in Bernstein und Kopal. Hirschberg: Publishing House J. Wunderlich.

Wunderlich, J. 2015. New and rare Arachnida in Cretaceous Burmese amber (Amblypygi, Ricinulei and Uropygi: Thelyphonida). In Beiträge zur Araneologie 9. Mesozoic Spiders: Spinnen des Erdmittelalters, ed. J. Wunderlich, 409-436. Hirschberg: Publishing House J. Wunderlich.

Xia, F., G. Yang, Q. Zhang, G. Shi, and B. Wang. 2015. Amber: life through time and space. Beijing: Science Press.

Zhang, W.W. 2017. Frozen dimensions. The fossil insects and other invertebrates in amber. Chongqing: Chongqing University Press. 